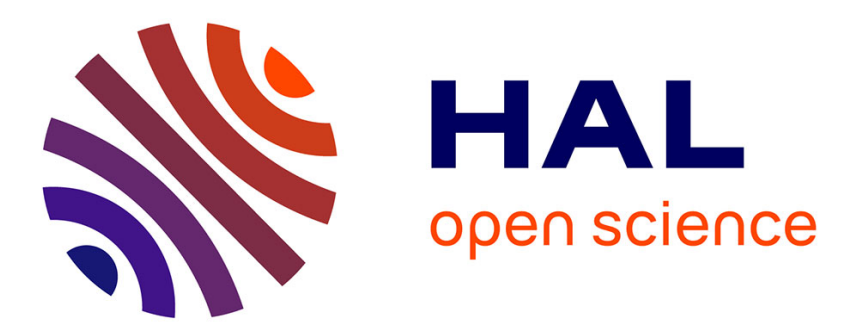

\title{
North Indian Ocean variability during the Indian Ocean dipole
}

\author{
J. Brown, C. A. Clayson, L. Kantha, T. Rojsiraphisal
}

\section{To cite this version:}

J. Brown, C. A. Clayson, L. Kantha, T. Rojsiraphisal. North Indian Ocean variability during the Indian Ocean dipole. Ocean Science Discussions, 2008, 5 (2), pp.213-253. hal-00298501

\section{HAL Id: hal-00298501 \\ https://hal.science/hal-00298501}

Submitted on 9 Jun 2008

HAL is a multi-disciplinary open access archive for the deposit and dissemination of scientific research documents, whether they are published or not. The documents may come from teaching and research institutions in France or abroad, or from public or private research centers.
L'archive ouverte pluridisciplinaire HAL, est destinée au dépôt et à la diffusion de documents scientifiques de niveau recherche, publiés ou non, émanant des établissements d'enseignement et de recherche français ou étrangers, des laboratoires publics ou privés. 
Ocean Sci. Discuss., 5, 213-253, 2008

www.ocean-sci-discuss.net/5/213/2008/

(C) Author(s) 2008. This work is distributed under

the Creative Commons Attribution 3.0 License.

Papers published in Ocean Science Discussions are under open-access review for the journal Ocean Science
OSD

5, 213-253, 2008

Indian Ocean variability during the IOD

J. Brown et al.

\section{North Indian Ocean variability during the Indian Ocean dipole}

\section{J. Brown ${ }^{1}$, C. A. Clayson ${ }^{1}$, L. Kantha ${ }^{2}$, and T. Rojsiraphisal ${ }^{3}$}

${ }^{1}$ Geophysical Fluid Dynamics Institute, Florida State University, Tallahassee, Florida, USA

${ }^{2}$ Department of Aerospace Engineering Sciences, University of Colorado, Boulder, Colorado, USA

${ }^{3}$ Department of Mathematics, Burapha University, Thailand

Received: 26 March 2008 - Accepted: 8 April 2008 - Published: 9 June 2008

Correspondence to: J. Brown (jbrown@gfdi.fsu.edu)

Published by Copernicus Publications on behalf of the European Geosciences Union.
Title Page

\section{Full Screen / Esc}

Printer-friendly Version

Interactive Discussion 


\section{Abstract}

The circulation in the North Indian Ocean (NIO henceforth) is highly seasonally variable. Periodically reversing monsoon winds (southwesterly during summer and northeasterly during winter) give rise to seasonally reversing current systems off the coast of

5 Somalia and India. In addition to this annual monsoon cycle, the NIO circulation varies semiannually because of equatorial currents reversing four times each year. These descriptions are typical, but how does the NIO circulation behave during anomalous years, during an Indian Ocean dipole (IOD) for instance? Unfortunately, in situ observational data are rather sparse and reliance has to be placed on numerical models 10 to understand this variability. In this paper, we estimate the surface current variability from a 12-year hindcast of the NIO for 1993-2004 using a 1/2 resolution circulation model that assimilates both altimetric sea surface height anomalies and sea surface temperature. Presented in this paper is an examination of surface currents in the NIO basin during the IOD. During the non-IOD period of 2000-2004, the typical equatorial circulation of the NIO reverses four times each year and transports water across the basin preventing a large sea surface temperature difference between the western and eastern NIO. Conversely, IOD years are noted for strong easterly and westerly wind outbursts along the equator. The impact of these outbursts on the NIO circulation is to reverse the direction of the currents - when compared to non-IOD years - during the summer for negative IOD events (1996 and 1998) and during the fall for positive IOD events (1994 and 1997). This reversal of current direction leads to large temperature differences between the western and eastern NIO.

\section{Introduction}

The overwhelming determinant of the circulation and its variability in the North Indian

Ocean (NIO) is the seasonally reversing monsoon winds (Schott and McCreary, 2001). During the boreal summer, the winds are from the southwest. The Southeast Trade
Indian Ocean variability during the IOD

J. Brown et al.

Title Page

Abstract

Introduction

Conclusions

Tables References

Figures

14

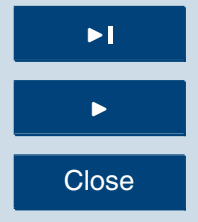

Back

Close

Full Screen / Esc

Printer-friendly Version

Interactive Discussion

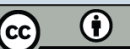


Winds south of the equator cross the equator and continue into the Arabian Sea in the form of a strong, southwesterly low-level jet along the Somali and Oman coasts, known as the Findlater Jet. Strong upwelling occurs along these coasts and the sea surface temperature (SST) is depressed by a few degrees. During the boreal winter the 5 winds are northeasterly and thus most major currents reverse their direction. Both the southwestward flowing Somali Current north of the equator and the northward flowing East African Coastal Current south of the equator turn eastward and feed the South Equatorial Countercurrent located just south of the equator (Kantha et al., 2008). Between the two monsoons, winds are westerlies along the equator and drive strong eastward-flowing surface jets along the equator known as Wyrtki-Yoshida Jets.

Because the winds are mostly westerlies along the equatorial waveguide, the sea surface height (SSH) is higher at the eastern side of the NIO basin. Only when the winds are anomalous and easterly does the equatorial Indian Ocean resemble the equatorial Pacific, where the prevailing winds are easterlies. The sea level is then 15 lowered at the eastern end of the basin while upwelling takes place along the equator. Superimposed on the "mean" circulation exists strong variability at various time scales ranging from synoptic to seasonal to interannual. The variability is moderate but can on occasion be quite large, e.g. during the Indian Ocean dipole (IOD). An IOD results when anomalously high and low SST pools occur on opposite sides of the NIO basin. 20 This causes changes in winds, clouds, and precipitation patterns as seen in Fig. 1 and discussed in many previous studies (Schott and McCreary, 2001; Vinaychandran et al., 2002; Webster et al., 1999, and references therein). The impact of the IOD on surface currents however is unknown because observations for the NIO have been rather sparse. No systematic monitoring system such as the TOGA-TAO array in the

25 Pacific exists here and appeal must often be made to satellites, which monitor only the conditions near the sea surface. Presented in this paper is an analysis of atmosphere and ocean parameters from a 12-year hindcast model to determine the effect of IOD events on surface currents.

\section{OSD}

5, 213-253, 2008

\section{Indian Ocean variability during the IOD}

J. Brown et al.

\section{Title Page}

\section{Full Screen / Esc}

Printer-friendly Version

Interactive Discussion 


\section{Model and data description}

The numerical model used for the hindcast of the NIO is the University of Colorado version of the Princeton Ocean Model (CUPOM). This primitive equation model uses

5 topographically conformal coordinates vertically and orthogonal curvilinear coordinates horizontally. More details regarding the basic features of CUPOM can be found in Kantha and Clayson (2000).

The model used for the 12-year hindcast for the NIO study has $1 / 2^{\circ}$ resolution horizontally and 38 sigma levels vertically. The simulation of the near surface circulation

10 is improved by increasing the vertical resolution density in the first 30 levels. Dataassimilation of altimetric sea surface height (SSH) anomalies and sea surface temperature (SST) for the CUPOM are described in great detail by Lopez and Kantha (2000a,b). Additionally, the 12-year hindcast - including numerous comparisons between observations - and the hindcast results are described in detail by Kantha et al. 15 (2008).

\section{The Indian Ocean dipole}

A significant feature of the interannual oceanic and atmospheric variability in the Indian Ocean is associated with the IOD. The positive (negative) mode of this dipole, shown in the left (right) panel of Fig. 1, occurs when a cooler (warmer) than average SST pool forms in the eastern (western) Indian Ocean and a warmer (cooler) than average SST pool forms in the western (eastern) Indian Ocean. Both positive and negative IOD events are marked by anomalously high surface wind stress (yellow arrows in Fig. 1) and areas of increased precipitation (white patches in Fig. 1). In addition to influencing the dominant air and sea patterns in the NIO, the IOD also affects the inhabitants of the region with weather extremes impacting the climate of India, Asia, Africa, and Australia, as well as the rest of the planet.
OSD

5, 213-253, 2008

Indian Ocean

variability during the IOD

J. Brown et al.

\section{Title Page}
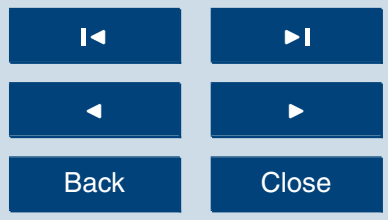

\section{Full Screen / Esc}

Printer-friendly Version

Interactive Discussion 
5 A quantitative determination of the IOD called the dipole mode index or DMI was developed by Vinaychandran et al. (2002). Following the same procedure, the DMI for the 12-year hindcast is estimated as the difference between the average SST anomalies over the western Indian Ocean $\left(50^{\circ} \mathrm{E}-70^{\circ} \mathrm{E}\right.$ and $\left.10^{\circ} \mathrm{S}-10^{\circ} \mathrm{N}\right)$ and the average SST anomalies over the eastern Indian Ocean $\left(90^{\circ} \mathrm{E}-110^{\circ} \mathrm{E}\right.$ and $\left.10^{\circ} \mathrm{S}-0^{\circ}\right)$, the two areas most affected by the IOD (Fig. 2). The resulting DMI in Fig. 3 is similar to that calculated by Vinaychandran et al. (2002, Fig. 2); i.e. the positive phase IOD events of 1994 and 1997, and the negative phase IOD event of 1996 are reflected in the assimilated SST hindcast data set. Negative DMI values are predominant because the normal SST difference observed across the NIO during non-IOD years is for a warmer

15 eastern end of the basin, though most such events are not as pronounced as those of 1996 and 1998 when the SST difference exceeds a normalized anomaly of -2 . The 1994 and 1997 positive phase IOD events both exceed a normalized anomaly value of three. There is no exacting DMI value recited in the literature that must be reached to qualify as a dipole. Instead, an IOD is qualified as such when the west-east SST 20 difference reaches a local maximum or minimum, and the zonal SST difference across the basin is reported as an indication of the strength of the dipole. Herein, 1994 and 1997 are analyzed as positive phase IOD events, while 1996 and 1998 are treated as negative phase IOD events due to each exceeding a normalized anomaly of two for a positive IOD and minus two for a negative IOD. In addition to the aforementioned IOD, 25 there is a noticeable trend of non-IOD events for 2000-2004. Thus the NIO circulation is analyzed as typical behavior (2000-2004) compared to the individual IOD years of 1994, 1996, 1997, and 1998.

\subsection{IOD signature}

Spectral decomposition of the DMI from Fig. 3 is completed using the wavelet power spectrum (WPS) developed by Torrence and Compo (1998). Throughout the 12-year

\section{Indian Ocean variability during the IOD \\ J. Brown et al.}

\section{Title Page}

Abstract Introduction

Conclusions

Tables References Figures
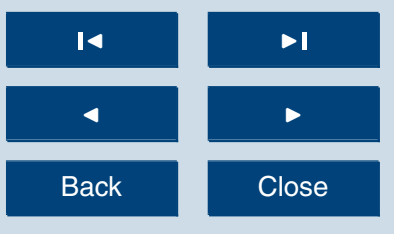

Full Screen / Esc

Printer-friendly Version

Interactive Discussion 
time record, the DMI varies with a period of 0.5 years-indicated as significant contours 5 in Fig. 4 (panel b) and the significant peak in the global wavelet spectrum (GWS) of Fig. 4 (panel c) - which likely corresponds to the "semiannual eastward winds over the equator" (Schott and McCreary, 2001). The peak in the GWS between two and three years is the result of anomalous SST differences for $1993^{1}, 1994,1996,1997$, and 1998, as indicated by significant contours in the WPS of Fig. 4 (panel b). Previously, IOD events were identified for 1994, 1996, 1997, and 1998 in Fig. 3. Summarily, the IOD signature derived from the characteristics of the WPS in Fig. 4 is described as having 2-3 year variability superimposed on the semiannual cycle for IOD events occurring for 1993 to 1999 , while 2000-2004 predominantly varies at the 0.5 year period and is devoid of any IOD events. Tozuka et al. (2007) similarly use a WPS to analyze the DMI resulting from a 200-year coupled general circulation model output and show significant energy throughout the 1990s for both 0.5 years and between two and four years (Tozuka et al., 2007, Fig. 3).

Though the IOD is an irregular temporal occurrence, wavelet decomposition of the DMI for this particular time record delineates between years with and without IOD 20 events when averaged for 2-3 years. For the 12-year hindcast period lasting from 1993 through 2004, the 2-3 year scale-average time series (SATS) in Fig. 4 (panel d) shows significant peaks during the IOD events of 1994, 1996, 1997, and 1998. Panel d of Fig. 4 is henceforth referred to as the IOD signature and is used to identify the effect of IOD events in other parameters through estimation of the 2-3 year SATS.

\subsection{Empirical orthogonal function analysis of SST}

Empirical orthogonal functions (EOFs) are typically used to analyze spatial and temporal variability in atmospheric and oceanic data. Often, however, EOF modes lack

\footnotetext{
${ }^{1}$ The significant contour for 1993 falls inside the cone of influence and thus the results are suspicious. The cone of influence itself arises from discontinuities at the endpoints due to zero padding to reach the dyadic record length necessary for wavelet decomposition (Torrence and Compo, 1998).
}

OSD

5, 213-253, 2008

Indian Ocean variability during the IOD

J. Brown et al.

Title Page

Abstract

Introduction

Conclusions

Tables

References

Figures

14

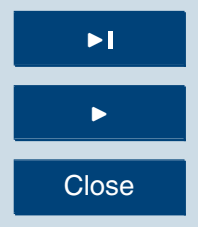

Back

Close

Full Screen / Esc

Printer-friendly Version

Interactive Discussion 
physical or dynamic interpretation beyond measures of statistical significance. Fur5 thermore, EOF modes are seldom the result of variability for a single period. For example, a single mode may be the result of both annual and interannual variability. To reduce a dynamic event such as the IOD, which does not occur at a regular period, to a single mode is difficult. Fortunately, SST variability for 1993-2004 is replete with several highly anomalous IOD events that do occur regularly during the 1990s. When analyzed using wavelet decomposition of EOF modes for SST, IOD events are conspicuous compared to non-IOD years because of their large SST variability and regularity. In particular, the temporal variability or principal component (PC) for the 4th SST mode in Fig. 5 closely resembles that of the IOD signature in Fig. 4: significant peaks are present for 0.5 and 2-3 years in the GWS (panel c), and the 2-3 year SATS (panel d) indicates that the 0.5 year period of variability is significant for all years, while the 2-3 year period of variability is exclusive to the 1990s.

Spatial variability for the 4 th SST mode, presented as a correlation map ${ }^{2}$ in Fig. 6 , occurs in areas encompassed by the DMI in Fig. 1. Physical interpretation of the 20 correlation map during the 1997-1998 IOD event, for example, follows that the blue (red) contours in Fig. 6 are areas of anomalously low (high) SST when considering the accompanying PC in Fig. 5 (panel a). The 4th mode explains only $2 \%{ }^{3}$ of the total variance of the SST field, but it is significantly different from noise according to Rule $\mathrm{N}$ for the record length and number of sampling locations (Overland and Preisendorfer,

\footnotetext{
${ }^{2}$ Correlation maps are preferred for presentation of the spatial variability of EOF analysis because of understanding (Venegas et al., 1997). Each contour shows how highly correlated the area is to the temporal variability or PC. For example, dark blue contours are areas of anomolously cold SST when the PC is anomalously positive as in 1994 and 1997.

${ }^{3}$ Though only $2 \%$ of the total variance is explained by the 4 th mode, Rule $\mathrm{N}$ and North's rule of thumb both suggest that the fourth mode is significant. Additionally, variability in the NIO is largely dominated by the annual cycle, which is usually associated with the monsoon. For the SST data in this study, the first three modes are dominated by the annual cycle and represent $86 \%$ of the total variance explained by the EOF decomposition.
}

OSD

5, 213-253, 2008

\section{Indian Ocean variability during the IOD}

J. Brown et al.

\section{Title Page}

\section{Full Screen / Esc}

Printer-friendly Version

Interactive Discussion 
1982). According to North's rule of thumb, the 4th mode is well separated from the 5 3rd and 5th modes when considering the 95\% significance level of each (North et al., 1982). Thus, the IOD signature is used to assign physical meaning to the spatial variability of the 4th SST mode by matching the temporal variability via the WPS with that of the IOD signature in Fig. 4 (panel d).

\section{NIO dynamic response to the IOD}

10 Section 3.3 shows the isolation of the IOD to the 4th SST EOF mode. As such, the 4th mode is identified as the IOD mode because Fig. 5 (panel d) matches the IOD signature of Fig. 4 (panel d) and the overlap between areas of high correlation in Fig. 6 and the boxes of the DMI in Fig. 2. The isolation of the IOD signature to a single SST EOF mode is next used to identify the IOD variability in other parameters through combined 15 EOF (cEOF). Without prior knowledge of NIO dynamics, physical interpretation of EOF modes becomes difficult. Aligning variability in other parameters with that of SST via $\mathrm{CEOF}^{4}$ analysis, however, estimates the simultaneous spatial and temporal variability of multiple parameters by coupling them into a single data matrix (Venegas et al., 1997; Venegas, 2001). In this study, the SST data field is paired with zonal surface wind stress (SWX), sea surface height (SSH), and zonal surface current (SCU). Analysis and the results for each pair are then referenced as: SST-SWX, SST-SSH, and SSTSCU. From the cEOF analysis of each pair, variability of each parameter is estimated

\footnotetext{
${ }^{4} \mathrm{cEOF}$ analysis is completed following the same procedure as for standard EOF analysis, with the exception of the handling of the data matrix. The parameter fields considered for analysis are normalized individually by their standard deviation, for each location, prior to being combined into a single, larger matrix. In instances where each variable is not sampled at the same locations, each measurement is further normalized by the total number of sample locations (Venegas, 2001). Normalization is imperative to avoid the numerical dominance of one parameter over the other. Though sample locations are not required to coincide, each parameter must have the same temporal sampling.
}

\section{OSD}

5, 213-253, 2008

Indian Ocean variability during the IOD

\section{J. Brown et al.}

\section{Title Page}

\section{Full Screen / Esc}

Printer-friendly Version

Interactive Discussion 
as a PC for temporal variability and a correlation map for spatial variability, as with SST

5 in Sect. 3.3. From the cEOF analysis, the IOD signature is first identified for a particular SST mode, and then variability in the corresponding mode for the coupled parameter - either SWX, SSH, or SCU - is thus associated with variability during the IOD.

\subsection{SST-SWX cEOF}

The cEOF analysis of SST and SWX estimates the 4th mode as the IOD signature from 10 comparing the signal in Fig. 4 (panel d) with that of the 2-3 year SATS for SST in Fig. 7 (black line). Both figures have significant peaks during the IOD years of 1994, 1995, 1997, and 1998. Rather than present the full WPS as in Figs. 4 and 5, only the 2-3 year SATS for SST is presented as an averaged summary of the WPS for comparison with the IOD signature in Fig. 4 (panel d). Variability for the 4th SWX mode is then attributed to the IOD. Temporal variability for SWX also has significant peaks for the 2-3 year SATS during IOD years (gray line in Fig. 7). Both time series show a peak during 1993, which, though not recognized as a negative IOD event, the DMI during 1993 shows a large negative SST anomaly across the NIO basin. Further comparison of the PCs for 4th modes of each parameter shows a correlation that is statistically significant $(0.5037)$ at the $95 \%$ level $(0.2441)$. The SCF explained is $0.5 \%$.

The statistically significant correlation between the time series of both variables supports the well established proposition that IOD events begin with an anomalous easterly or anomalous westerly wind burst near $90^{\circ} \mathrm{E}$ at the equator (Schott and McCreary, 2001; Vinaychandran et al., 2002; Webster et al., 1999). This location is also found to eas of high zonal wind stress variability in Fig. 8 coincide with the dynamic explanation of Fig. 1.

\section{OSD}

5, 213-253, 2008

Indian Ocean variability during the IOD

J. Brown et al.

\section{Title Page}

Abstract

\section{Full Screen / Esc}

Printer-friendly Version

Interactive Discussion 


\subsection{SST-SSH cEOF}

As was the case for SWX, the cEOF analysis of SST with SSH returns the 4th mode as the IOD mode in the SST parameter. Comparing the IOD signature in Fig. 4 (panel d) 5 with that of the 2-3 year scale-averaged time series (SATS) of the 4th SST mode (black line in Fig. 9) shows both signals as having significant variability during the IOD years of 1994, 1996, 1997, and 1998. The corresponding 4th SSH mode has significant peaks for 1996 and 1997, and localized peaks for 1994 and 1998 (gray line in Fig. 9). The lack of significant peaks during 1994 and 1998 indicates a weaker relationship between SST and SSH variability during these years. Correlation between the PCs for the 4th mode of SSH and SST (0.5934) is greater than the $95 \%$ level of 0.3020 for statistical significance (Sciremammano, 1979). The square covariance fraction (SCF), analogous to the percent of total variance for the EOF analysis of a single parameter, is $2 \%$.

15 The area of highest positive correlation for spatial variability (Fig. 10) shows high negative and positive correlation in areas overlapping with those of the DMI boxes in Figure 2. Spatial variability in the correlation map of Fig. 10 appears to show the existence of upwelling Kelvin waves - blue, negative contours to the east - and downwelling Rossby waves - red, positive contours to the west. The IOD is known to begin 20 with a sharp and lasting easterly wind anomaly centered near the equator and $90^{\circ} \mathrm{E}$ (yellow arrows in Fig. 1). The result of such an outburst would produce Kelvin waves propagating eastward and then north and south along the coast, with complimentary Rossby waves propagating westward. Webster et al. (1999) also attributed the deepening of the thermocline in the western NIO during the 1997 IOD to westward-propagating

25 Rossby waves occurring south of the equator. Deepening the thermocline in the western NIO serves to increase the SST anomaly off the coast of Oman, thereby enhancing a positive IOD event. Though EOF analysis is not typically associated with propagating waves, persistent variability in $\mathrm{SSH}$ in this case is resolved as spatial variability associated with the 4th mode. The pattern of the blue contours in the eastern NIO of Fig. 10

OSD

5, 213-253, 2008

\section{Indian Ocean variability during the IOD \\ J. Brown et al.}

\section{Title Page}


suggests Kelvin waves reaching land and traveling as coastal Kelvin waves. Further, the location of the area affected by downwelling (red contours) is consistent with the results of Webster et al. (1999).

\section{$5 \quad 4.3$ SST-SCU cEOF}

Having established the cEOF analysis for SST paired with both SWX and SSH as estimating the temporal and spatial variability consistent with IOD dynamic explanations in the literature, the same approach is taken to estimate the zonal surface current (SCU) variability during IOD events. One of the primary interests in using the CUPOM data set is the inclusion of surface current information because of the lack of observations of currents in the NIO basin. Using the model results and again working with the cEOF analysis, which identifies the portion of the NIO basin affected by the IOD, this deficiency can be remedied.

Consistent with the results for the IOD signature, the 2-3 year SATS for the 4th SST black line in Fig. 11 has significant variability during 1994, 1996, 1997, and 1998. Thus, temporal variability in zonal surface current (SCU) of the 4th mode is attributed to the IOD. The correlation between the principal components (PCs) for the cEOF analysis of SST and SCU is 0.3026 (95\% significance level is 0.2914$)$. The SCF for the coupled 20 4th mode is $0.7 \%$; modal variability for the SST-SCU pair is again dominated by the annual cycle.

Spatial variability for the 4th SCU mode (Fig. 12) is along the equator extending from east to west across the NIO basin. The results for SWX - an equatorial patch of high correlation in Fig. 8 - complement the equatorial current variability during IOD events. Though the direction of the equatorial surface current is known to reverse periodically for a given year, the results in Figs. 11 and 12 show anomalous variability during IOD years and raises the question as to whether a change in the pattern of equatorial current reversal would produce the levels of water transport necessary to produce positive and negative dipoles.
OSD

5, 213-253, 2008

Indian Ocean variability during the IOD

J. Brown et al.

\section{Title Page}

Abstract

\section{Full Screen / Esc}

Printer-friendly Version

Interactive Discussion 


\section{NIO zonal surface current variability}

According to ship-drift climatology, the equatorial NIO current reverses direction three 5 times during the year. During the monsoons in winter and summer, the equatorial current flows westward. The reversal of currents eastward during spring and fall creates Wyrtki Jets with current speeds approaching $100 \mathrm{~cm} \mathrm{~s}^{-1}$. Wyrtki Jets occur during the period between the monsoons and serve to carry warmer surface water from the western NIO to the eastern side of the basin (Schott and McCreary, 2001). The result of the warm water transport between the monsoons is to increase (decrease) the SST and SSH in the eastern (western) NIO.

\subsection{Zonal surface current during 2000-2004}

The previous description of the typical current motion is observed in Fig. 13 for zonal surface currents during the non-IOD years of 2000-2004. The currents are daily averaged near the equator $\left(3^{\circ} \mathrm{S}\right.$ to $\left.0^{\circ}\right)$ in the region most affected by the IOD in Fig. 12. Spring and fall eastward flowing currents (black contours in Fig. 13) result in negative DMI values during 2000-2004 in Fig. 3. In contrast, positive DMI values occur during the winter and summer for 2000-2004 in Fig. 3 because of westward flowing currents represented as gray contours in Fig. 13. The continuous reversal of equatorial surface currents transports water during non-IOD years to prevent the NIO from achieving a west-east dipole in SST difference. As will be shown in the following sections, the IOD events observed in 1994, 1996, 1997, and 1998 are a product of changes in equatorial winds.

\subsection{Zonal surface currents for the positive IOD events of 1994 and 1997}

25 The DMI in Fig. 3 shows the SST difference exceeding a normalized anomaly value of positive two during 1994 and 1997. Warming of the western NIO for both years follows a similar pattern: strong eastward flowing (positive) currents in the spring are followed

OSD

5, 213-253, 2008

Indian Ocean variability during the IOD

J. Brown et al.

\section{Title Page}

\section{Full Screen / Esc}

Printer-friendly Version

Interactive Discussion 
by an extended period of predominantly westward flowing (negative) currents for the summer and fall. Figure 15 shows the evolution of the equatorial zonal surface current pattern for 1994, while the same is given for 1997 in Fig. 14.

5 The 1997 IOD event, in particular, stands out as one of the most intense and important dynamic demonstrations of air-sea interaction in the Indian Ocean basin during the hindcast time period. As a result, much of the discussion in the literature surrounding IOD events has centers on the 1997 event - sometimes referred to as the 1997-1998 event. The positive IOD of 1997 is characterized as an anomalously warm west-to-east 10 SST difference (Webster et al., 1999, Fig. 1a) supported by an easterly wind outburst (Webster et al., 1999, Fig. 1b) and the westward flowing equatorial current (Fig. 15). Both the easterly wind outburst and westward flowing equatorial, zonal surface current last until May of 1998. The positive IOD of 1994 follows the same pattern with the exception being that the westward flowing (negative) currents cease in November.

15 Compared to Fig. 13, the equatorial current would have reversed to eastward flowing during the winter of 1997 if not for the IOD. Instead, the current remained westward flowing into the winter where the SST warm pool was further enhanced in the western NIO by the monsoon. Webster et al. (1999) credits Ekman transports and Rossby waves for deepening the western NIO thermocline, causing the SST to increase and 20 suppressing the summer monsoon-induced coastal upwelling. If the equatorial current had reversed, as is the case during non-IOD years, the warmer western water would have been transported eastward to diminish the SST difference across the basin and eliminate the IOD. The IOD instead strengthened to a normalized SST difference anomaly of four (Fig. 3) and the current persisted westward through the end of the year 25 and into the next. Ironically, the spring equatorial surface currents are strongest eastward flowing during 1997 compared to any of the 12 hindcast years. 1997 is also the strongest positive IOD which seemingly contradicts the large positive (eastward flowing) currents which would create a buildup of warm surface water in the eastern NIO resulting in a negative IOD.

\section{OSD}

$5,213-253,2008$

Indian Ocean variability during the IOD

J. Brown et al.

\section{Title Page}

Abstract Introduction

Conclusions

Tables References Figures
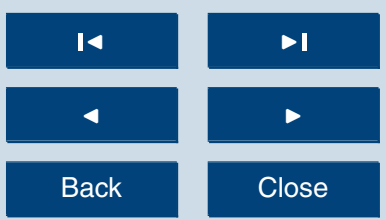

Full Screen / Esc

Printer-friendly Version

Interactive Discussion 


\subsection{Zonal surface currents for the negative IOD events of 1996 and 1998}

As occurred for positive and non-IOD years, the spring reversal of the equatorial currents is also present for 1996 (Fig. 17) and 1998 (Fig. 16). For each of the 12 hindcast

5 years the DMI in Fig. 3 is predominantly positive for the first half of the year. The spring current reversal at the midpoint of each year causes a substantial reversal in the DMI. The obvious difference between positive and negative IOD events is the direction of the equatorial currents during the summer and fall: westward flowing (negative) currents exist for positive IOD events, while currents are eastward flowing (positive) during negative IOD events. These findings are consistent with the direction of water transport necessary to achieve the correct dipole difference in SST for each respective event.

An interesting feature of the negative IOD events of 1996 and 1998 is the dichotomous equatorial current pattern of strong westward flowing (gray, negative contours in Figs. 17 and 16) currents in the western NIO coupled with eastward flowing (black, 15 positive contours in Figs. 17 and 16) currents in the eastern NIO. This pattern, not observed neither positive nor non-IOD years, occurs during August-September-October. Westward flowing currents reaching $50 \mathrm{~cm} \mathrm{~s}^{-1}$ in the western NIO are countered by eastward flowing currents reaching $70 \mathrm{~cm} \mathrm{~s}^{-1}$ in the eastern half of the basin. Divergent equatorial surface currents near $70^{\circ} \mathrm{E}$ are consistent with atmospheric divergence at the ocean's surface and bring colder water to the surface for transportation to opposite sides of the basin. The effect of this event on the DMI is discussed in Sect. 6.

\subsection{Effect of zonal wind stress on zonal surface currents}

Because equatorial surface currents are wind dominated, the behavior of the SCU is largely a result of anomalous winds. Sharp changes in the equatorial winds appear this conjecture, the zonal wind stress $(\mathrm{SWX})$ is averaged over the area denoted in the correlation map of Fig. 8 as being most affected by the IOD $\left(5^{\circ} \mathrm{S}\right.$ to $5^{\circ} \mathrm{N}$, and $70^{\circ} \mathrm{E}$ to $95^{\circ} \mathrm{E}$ ). Averaging over this area produces the wind stress index, referred to here
OSD

5, 213-253, 2008

Indian Ocean

variability during the IOD

J. Brown et al.

\section{Title Page}

Abstract

\section{Full Screen / Esc}

Printer-friendly Version

Interactive Discussion 
as WSI2. Comparing WSI2 with the DMI and SCU for daily averaged values between 2000 and 2004, as in Fig. 18, shows the dynamic relationship between the SST, SCU, and SWX (Fig. 18). The early part of each year is marked by negative SCU and WSI2, where zonal currents induce a slight water buildup and increased SST in the western 5 NIO until the peak during the spring. The spring and fall current reversals are shown in Fig. 18 (black line) as sharp peaks for May and September, respectively.

The SST for the NIO basin appears to be reacting to or lagging the equatorial zonal surface currents estimated as SCU in Fig. 18 (black line). The DMI spring-peak is prevented from increasing by the sharp reversal of the zonal winds (WSI2), and con10 sequently the zonal surface currents (SCU). Eastward flowing currents (positive SCU) begin to transport the warmer western water across the basin during the spring - creating the summer DMI peak of approximately-1 - and then reverse westward (negative SCU) for the summer and thus prevent the negative DMI peak from growing into an IOD. The dominance of westward flowing summer currents also begins the buildup of 15 warmer water in the western NIO to create the peak in DMI observed in the fall. WSI2 remains positive (as westerly winds) throughout the spring and summer before decreasing to negative for the fall and winter (as easterly winds). The currents, however, reverse direction again from westward in the summer to eastward in the fall (positive $\mathrm{SCU})$ to produce a reversal in the DMI from negative to positive. Eastward flowing 20 currents lasting throughout the fall then continue the cycle of water distribution across the basin by transporting the accumulated warmer, western waters to the eastern NIO to reduce the fall DMI peak.

Wind bursts during the spring and fall (shown in Fig. 18 as sharp gray peaks) initiate the reversal of equatorial currents. During the summer and fall however, when equatorial winds are positive and negative respectively, the equatorial current flows opposite to the direction of the surface wind stress calculated by WSI2. As shown previously in Figs. 9 and 10, an area of anomalous wind covering $5^{\circ} \mathrm{S}$ to $5^{\circ} \mathrm{N}$ and $80^{\circ} \mathrm{E}$ to $95^{\circ} \mathrm{E}$ is active during IOD events. The daily average for non-IOD years (black line labeled SCU in Fig. 18) is characterized by equatorial current south of the equator that flow

\section{OSD}

5, 213-253, 2008

\section{Indian Ocean \\ variability during the IOD \\ J. Brown et al.}

\section{Title Page}

Abstract

\section{Full Screen / Esc}

Printer-friendly Version

Interactive Discussion 
westward during the summer and eastward in the fall. The direction of the currents for both periods is consistent with those with those south of the equator during the summer and winter monsoons noted by Schott and McCreary (2001). Also, zonal surface winds calculated by WSI2 are consistent with the monsoons, i.e. westerlies in the summer 5 and easterlies in the winter.

In contrast to non-IOD years, IOD events are characterized by strong outbursts in equatorial winds that drive the zonal surface currents independent of the monsoon winds. Figure 20 compares the 1997 zonal surface currents (green line) with those of the 2000-2004 daily average (black line). The usual July decrease in the DMI occurring 10 for non-IOD years (red line in Fig. 18) is instead attenuated during 1997 by the persistent, wind-driven summer currents (green line in Fig. 20) which are eastward flowing and serve to establish a positive dipole. The positive DMI value is then increased further when the currents, now reversed from their 2000-2004 counterparts, continue as westward flowing throughout the remainder of 1997 and into 1998. Unlike 2000-2004, 15 covered by WSI2 instead of the monsoon winds as discussed above. This difference in
wind source - equatorial surface currents driven by WSI2 winds rather than the monsoons - is present for the summer, fall, and winter and is shown as overlapping gray and green lines for the IOD events of 1994 (Fig. 19), 1996 (Fig. 21), 1997 (Fig. 20), 20 and 1998 (Fig. 22).

Positive IOD events, discussed previously for FigS. 14 and 15, are characterized by strong eastward flowing equatorial currents in the spring followed by westward flowing equatorial currents throughout the fall. Furthermore, this pattern creates a fall peak in the DMI, and a reversal in direction of the fall and winter currents compared to those of the 2000-2004 daily average. Negative IOD events differ from positive events as to the seasonal peak in the DMI. A summer DMI peak for both 1996 and 1998 is attributable to the summer reversal of zonal equatorial currents from westward flowing (negative) to eastward flowing (positive). The currents are once again driven by winds in the WSI2 region. As previously noted, negative IOD events are also characterized in this study
OSD

5, 213-253, 2008

Indian Ocean variability during the IOD

J. Brown et al.

\section{Title Page}

Abstract Introduction

Conclusions

Tables References Figures

14

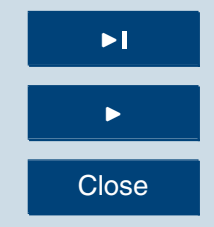

Back

Close

Printer-friendly Version

Interactive Discussion 
as achieving a DMI value of minus two and persisting for the second half of the year in question. Figure 3 shows the mid-2002 DMI as approaching minus two, though it is not 5 considered here as a negative IOD event because of the brevity of this event compared to those of 1996 and 1998, which both lingered into the following year.

\section{Conclusions}

The Indian Ocean dipole (IOD) is an important part of the air-sea dynamics of the North Indian Ocean (NIO) because of its affect on local climatology and global weather 10 patterns. Many researchers have studied variability in various parameters during the anomalous IOD years, such as sea surface temperature, sea surface height, zonal wind stress, and precipitation. Presented here are results from the analysis of the NIO circulation from surface current data - specifically zonal surface currents - produced by a 12-year hindcast using a circulation model during the period 1993-2004, which 15 included two positive and two negative IOD events. The lack of in situ measurements in the NIO and the dramatic change in local climatology during the IOD underscores the importance of these results.

Before analyzing the zonal surface current (SCU) data, the model was verified to produce the IOD events of 1994, 1996, and 1997 through estimation of the dipole mode 20 index or DMI (Vinaychandran et al., 2002). A wavelet power spectrum (Torrence and Compo, 1998) was then employed to estimate an IOD signature from the DMI. The IOD signature was next used to identify the IOD mode of the EOF analysis of sea surface temperature (SST), sea surface height (SSH), and zonal wind stress (SWX). Variability for these parameters is well understood, thus providing a verification measure for the process prior to analyzing the SCU. Zonal surface current variability was then found to be primarily along the equator during the IOD events of 1993-2004.

Having identified the area of variability for the SCU, the role of equatorial zonal surface currents during the IOD was analyzed. During the non-IOD years of 2000-2004, the equatorial SCU reverses four times each year and transports water across the

\section{Indian Ocean variability during the IOD \\ J. Brown et al.}

\section{Title Page}

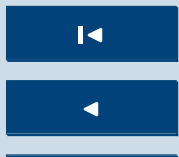
$\Delta$

\section{Full Screen / Esc}

Printer-friendly Version

Interactive Discussion 
basin preventing a large SST difference between the western and eastern NIO. Conversely, IOD years are noted for strong easterly and westerly wind outbursts along the equator. The impact of these outbursts on the NIO circulation is to reverse the direction of the currents - when compared to non-IOD years - during the summer for 5 negative IOD events (1996 and 1998) and during the fall for positive IOD events (1994 and 1997). Webster et al. (1999) notes the role of downwelling Rossby waves in suppressing the coastal upwelling due to the summer monsoon for the 1997 positive IOD mode. But the results in this study show the equatorial SCU as more than just a passive observer for NIO air-sea interaction. The easterly wind burst along the equator in 10 mid-1997 is strong and persistent enough to reverse the typical fall equatorial current direction to westward. The result of the current reversal is the westward transport of warm water from the eastern $\mathrm{NIO}$, which is warmed each summer by the eastward flowing, equatorial spring current. The warmer water increases the SSH and deepens the thermocline to reduce the effect of coastal upwelling from the summer monsoon.

15 For 1997, the reversal of the current persists into the winter when the monsoon-induced coastal downwelling is combined with the westward flowing current to further enhance the warming of the SST in the western NIO and extend the duration of the positive NIO. This complex interaction between the ocean surface and the atmosphere - also occurring during the IOD years of 1994, 1996, and 1998 - suggests an ENSO-like feedback involving zonal wind stress, SST, and the atmospheric pressure gradient.

Acknowledgements. Wavelet software was provided by C. Torrence and G. Compo, and is available at URL: http://paos.colorado.edu/research/wavelets/.

\section{References}

Kantha, L. H. and Clayson, C. A.: Numerical Models of Oceans and Oceanic Processes, 940 $25 \quad$ pp., Academic Press, San Diego, California, USA, 2000.

Kantha, L. H., Rojsiraphaisal, T., and Lopez, J. W.: The north Indian Ocean circulation and its

\section{OSD}

$5,213-253,2008$

Indian Ocean

variability during the IOD

J. Brown et al.

\section{Title Page}

\section{Full Screen / Esc}

Printer-friendly Version

Interactive Discussion 
variability as seen in a numerical hindcast of the years 1993 to 2004, Progress in Oceanography, 76, 111-147, 2008.

Lopez, J. W. and Kantha, L. H.: Results from a numerical model of the northern Indian Ocean: circulation in the South Arabian Sea, J. Mar. Syst., 24, 97-117, 2000a.

Lopez, J. W. and Kantha, L. H.: A data-assimilative model of the north Indian Ocean, J. Atmos. Oceanic Technol., 17, 1525-1540, 2000b.

5 North, G. R., Bell, T. L., Cahalan, R. F., and Moeng, F. J.: Sampling error in the estimation of empirical orthogonal functions, Mon. Wea. Rev., 110, 699-706, 1982.

Overland, J. E. and Preisendorfer, R. W.: A significance test for principal components applied to a cyclone climatology, Mon. Wea. Rev., 110, 1-4, 1982.

Schott, F. A. and McCreary, J. P.: The monsoon circulation of the Indian Ocean, Progress in Oceanography, 51, 1-123, 2001.

Sciremammano, F.: A suggestion and resentation of correlations and their significance levels, J. Phys. Oceanogr., 9, 1273-1276, 1979.

Torrence, C. and Compo, G. P.: A practical guide to wavelet analysis, Bull. Amer. Meteor. Soc., 79, 61-78, 1998.

15 Tozuka, T., Luo, J., Masson, S., and Yamagata, T.: Decadal modulations of the Indian Ocean dipole in the SINTEX-F1 coupled GCM, J. Climate, 20, 2881-2894, 2007.

Venegas, S. A.: Statistical methods for signal detection in climate, Danish Center for Earth System Science (DCESS) Report \#2, 96 pp., Niels Bohr Institute for Astronomy, Physics and Geophysics, University of Cophenhagen, Denmark, 2001.

Venegas, S. A., Mysak, L. A., and Straub, D. N.: Atmosphere-ocean coupled variability in the South Atlantic, J. Climate, 10, 2904-2920, 1997.

Vinaychandran, P. N., lizuka, S., and Yamagata, T.: Indian Ocean dipole mode events in an ocean general circulation model, Deep-Sea Res. Part II, 49, 1573-1596, 2002.

Webster, P. J., Moore, A. M., Loschnigg, J. P., and Leben, R. R.: Coupled ocean-atmosphere dynamics in the Indian Ocean during 1997-98, Nature, 401, 356-360, 1999.

\section{OSD}

$5,213-253,2008$

Indian Ocean variability during the IOD

J. Brown et al.

\section{Title Page}

Abstract

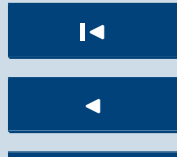

\section{Full Screen / Esc}

Printer-friendly Version

Interactive Discussion 
OSD

5, 213-253, 2008
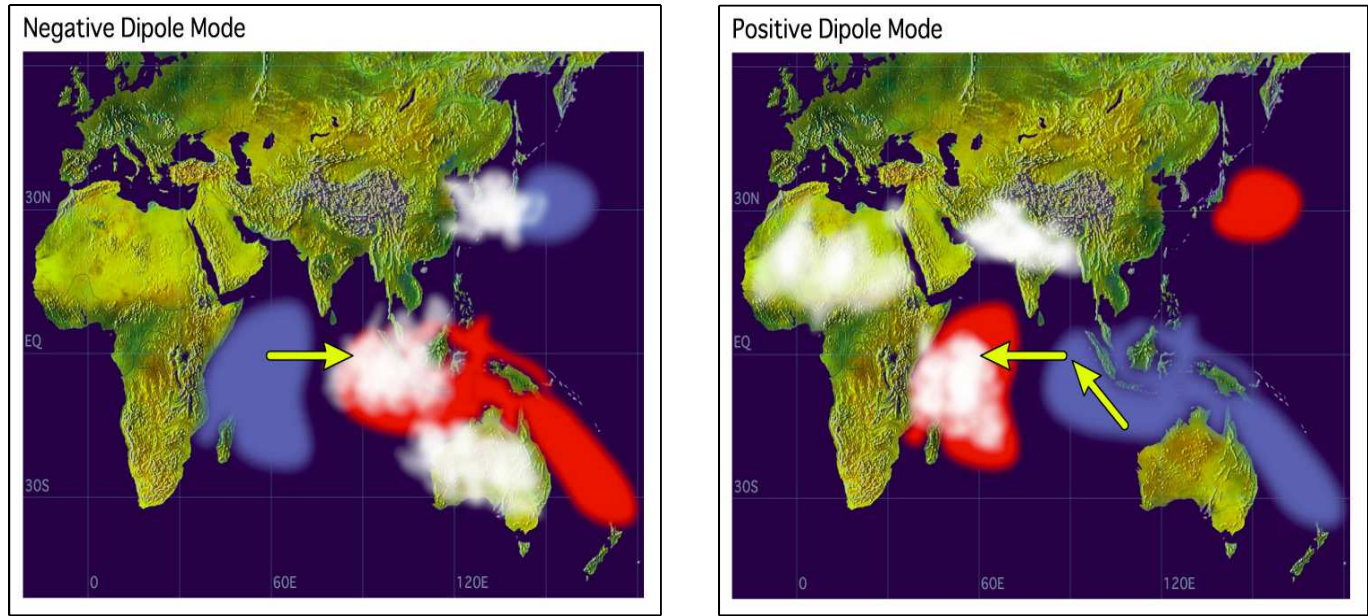

Indian Ocean variability during the IOD

\section{J. Brown et al.}

\section{Title Page}

Abstract

Introduction

Conclusions

References

Tables

Figures

14

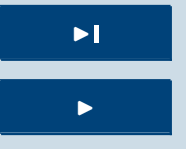

Back

Close

\section{Full Screen / Esc}

Printer-friendly Version

Interactive Discussion 
OSD

5, 213-253, 2008

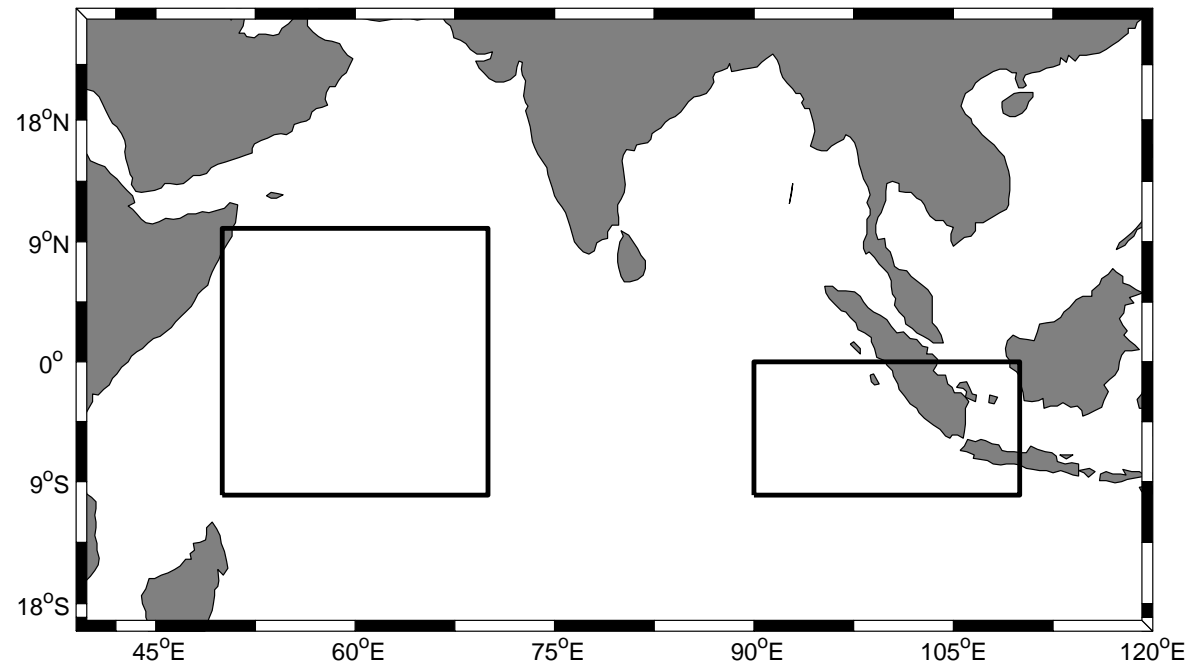

Fig. 2. Boxes show areas used to calculate the DMI specified by Vinaychandran et al. (2002). 


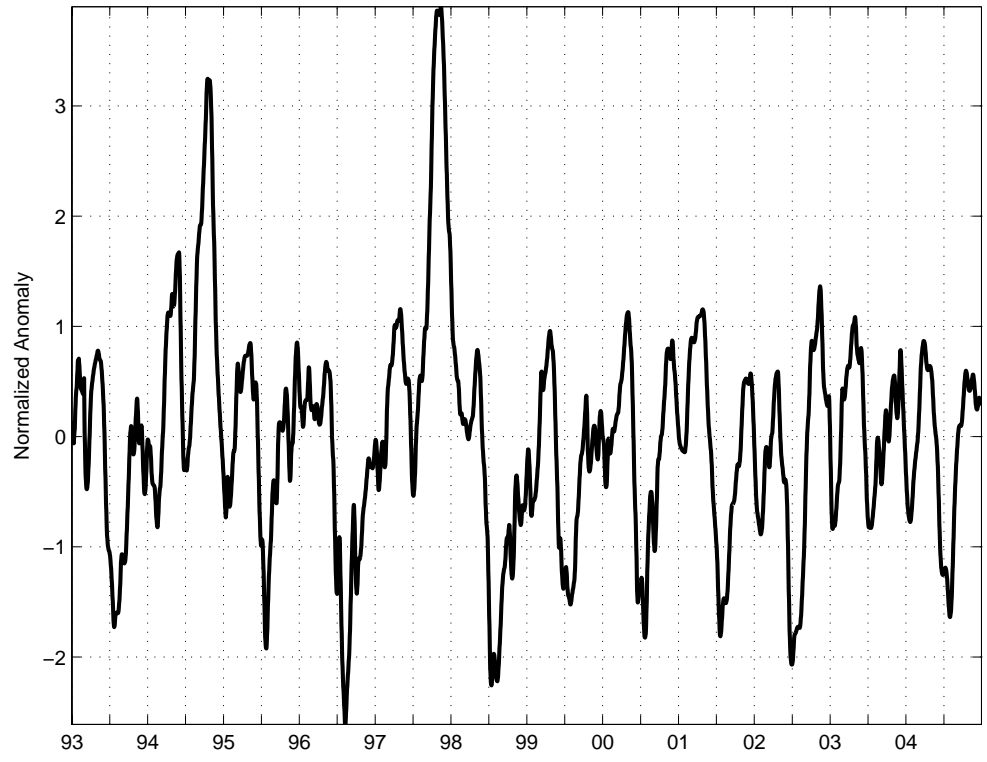

Indian Ocean variability during the IOD

\section{J. Brown et al.}

\section{Title Page}
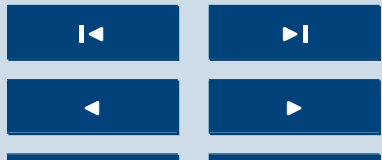

Fig. 3. Calculated DMI from the anomaly in SST when subtracting the area average for the west and east boxes in Fig. 2. The time series has the mean removed and is normalized by its standard deviation. IOD events for 1994, 1996, 1997, and 1998 appear as SST anomalies (Vinaychandran et al., 2002).

\section{Full Screen / Esc}

Printer-friendly Version

Interactive Discussion 


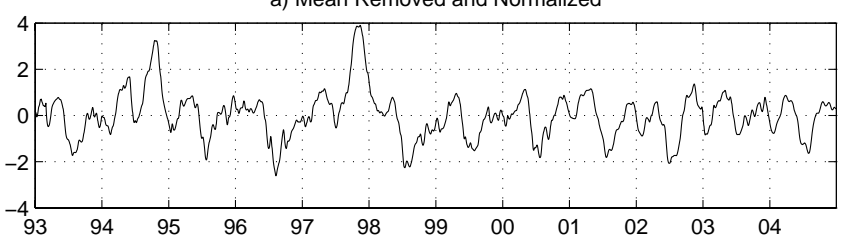

\section{OSD}

5, 213-253, 2008

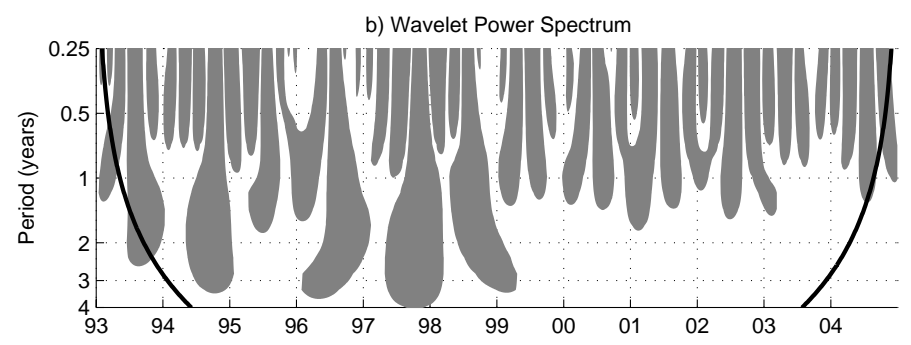

c) Global Wavelet Spectrum

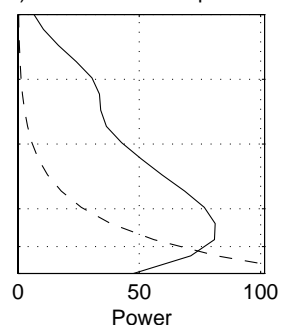

d) 2-3 Year Scale-average Time Series

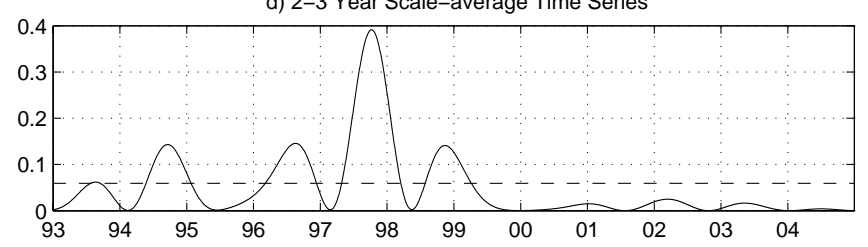

Indian Ocean variability during the IOD

J. Brown et al.

\section{Title Page}

Abstract

Introduction

Conclusions

References

Tables

Figures

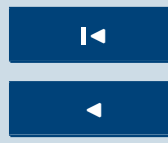

Back

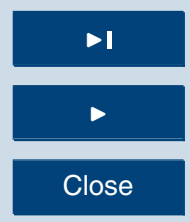

Full Screen / Esc

Printer-friendly Version

Interactive Discussion analysis. Panel c, the GWS, is estimated by averaging across the time record (horizontally) at each period. Panel d, the SATS, is estimated by averaging vertically across the two-three year period for each day of the time record. 
OSD

5, 213-253, 2008

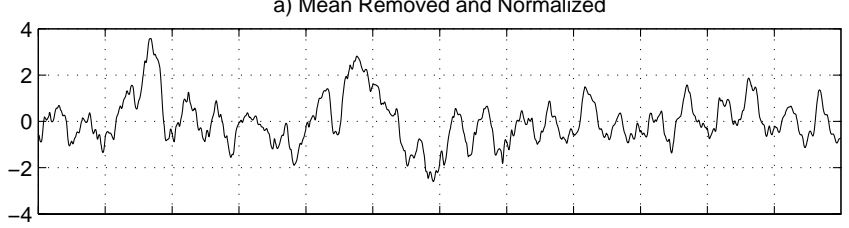

b) Wavelet Power Spectrum

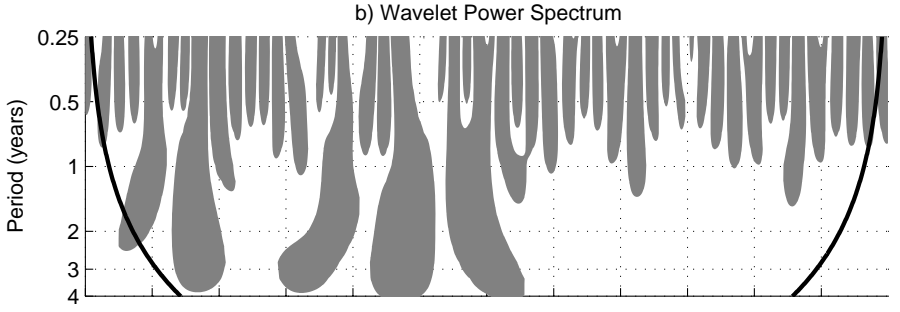

c) Global Wavelet Spectrum
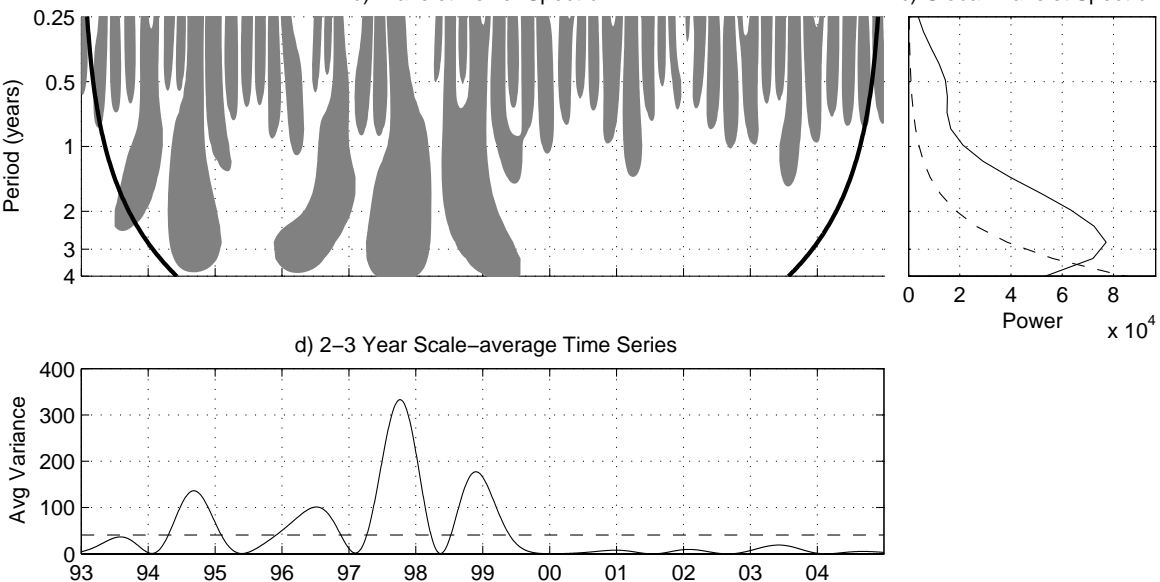

Fig. 5. Wavelet analysis of the principal component of the 4th SST mode, which explains $2 \%$ of the total variance. Each of the panel descriptions and the wavelet parameters used for significance are the same as for Fig. 4.
Indian Ocean variability during the IOD

J. Brown et al.

\section{Title Page}

Abstract

Introduction

Conclusions

References

Tables

Figures

14

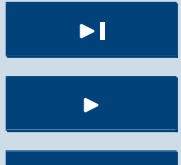

Back

Close

\section{Full Screen / Esc}

Printer-friendly Version

Interactive Discussion 
OSD

5, 213-253, 2008

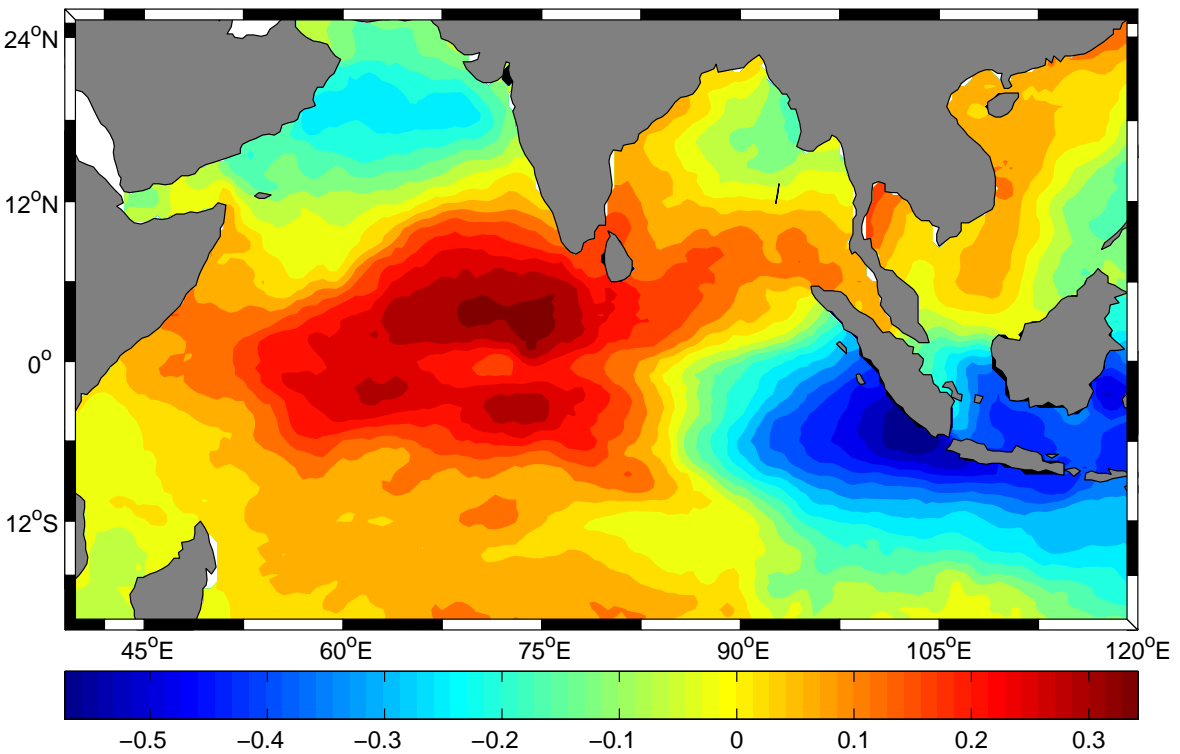

Indian Ocean variability during the IOD

\section{J. Brown et al.}

\section{Title Page}

Abstract

Introduction

Conclusions

References

Tables

Figures

14

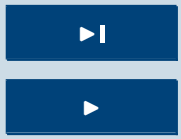

Back

Close

Full Screen / Esc

Printer-friendly Version

Interactive Discussion 


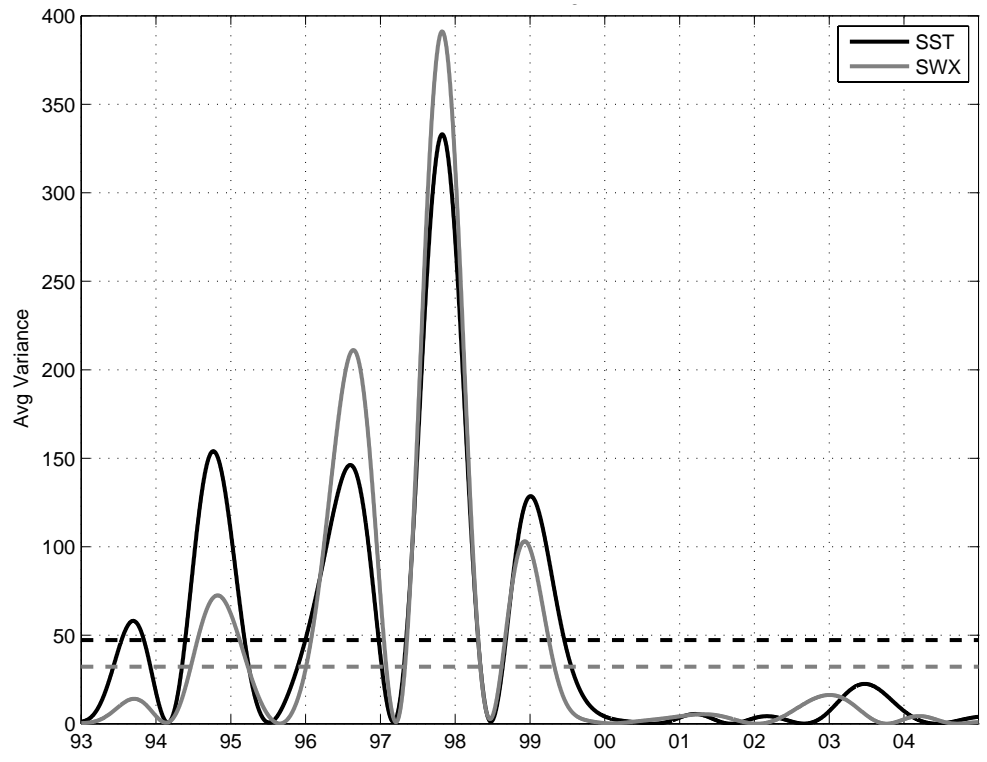

Indian Ocean variability during the IOD

J. Brown et al.

Title Page

\section{Abstract}

Conclusions

Tables

14

4

References

Figures

\section{Full Screen / Esc}

Printer-friendly Version

Interactive Discussion 


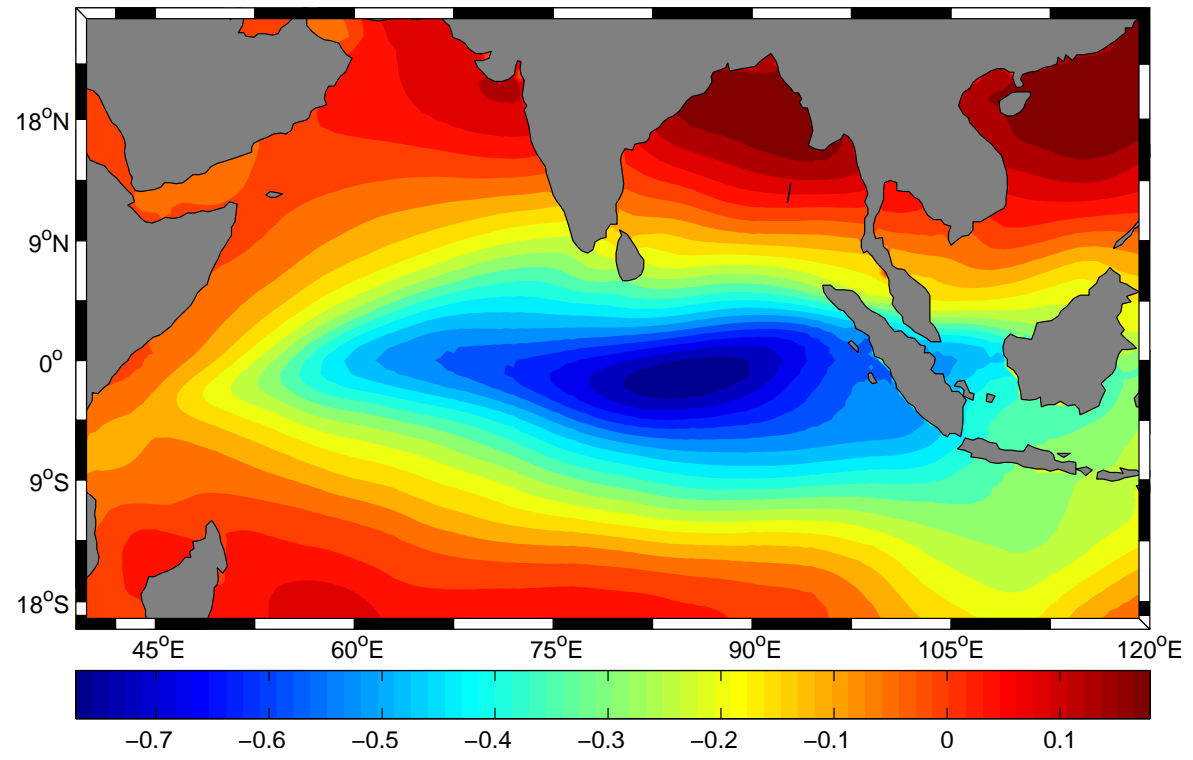

Fig. 8. Correlation map of the 4th SWX mode from cEOF analysis with SST. The area of anomalously high SWX in the eastern Indian Ocean occurs along the equator (as in Fig. 1), with contours greater than \pm 0.128 (in absolute value) being statistically significant at the $95 \%$ level.
Indian Ocean variability during the IOD

\section{J. Brown et al.}

\section{Title Page}

Abstract

Introduction

Conclusions

References

Tables

Figures

14

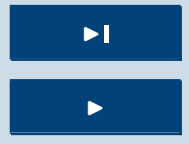

Back

Close

Full Screen / Esc

Printer-friendly Version

Interactive Discussion 


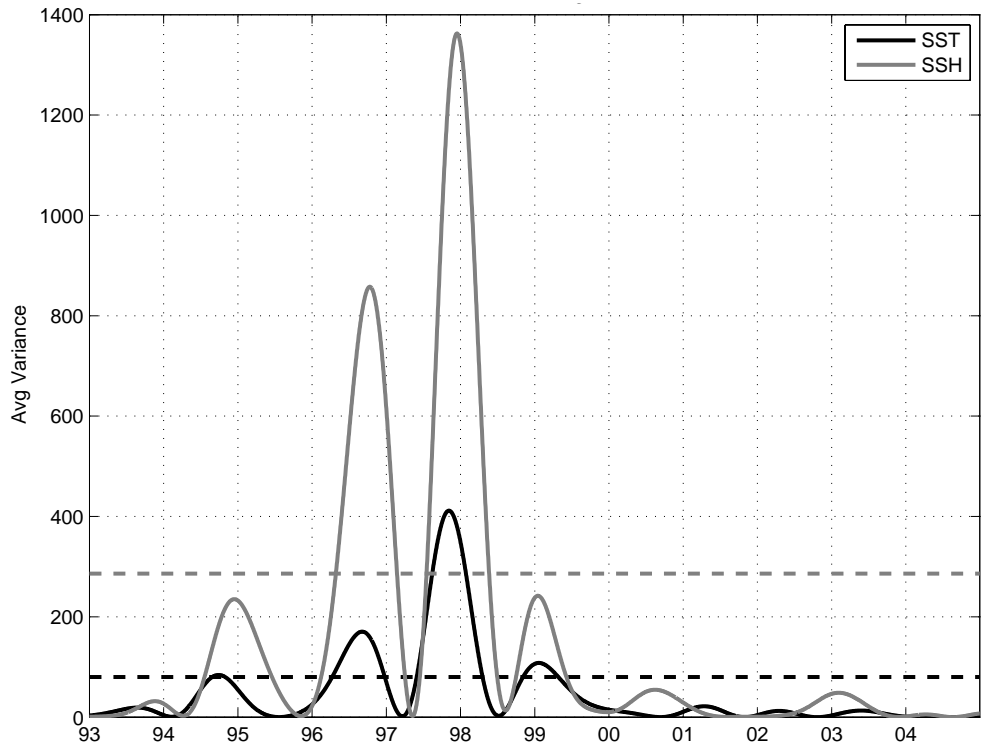

Indian Ocean variability during the IOD

J. Brown et al.

Title Page

\section{Abstract}

Conclusions

Tables

14

References

\section{Figures}

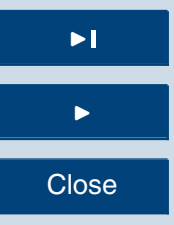

Full Screen / Esc

Printer-friendly Version

Interactive Discussion 
OSD

5, 213-253, 2008

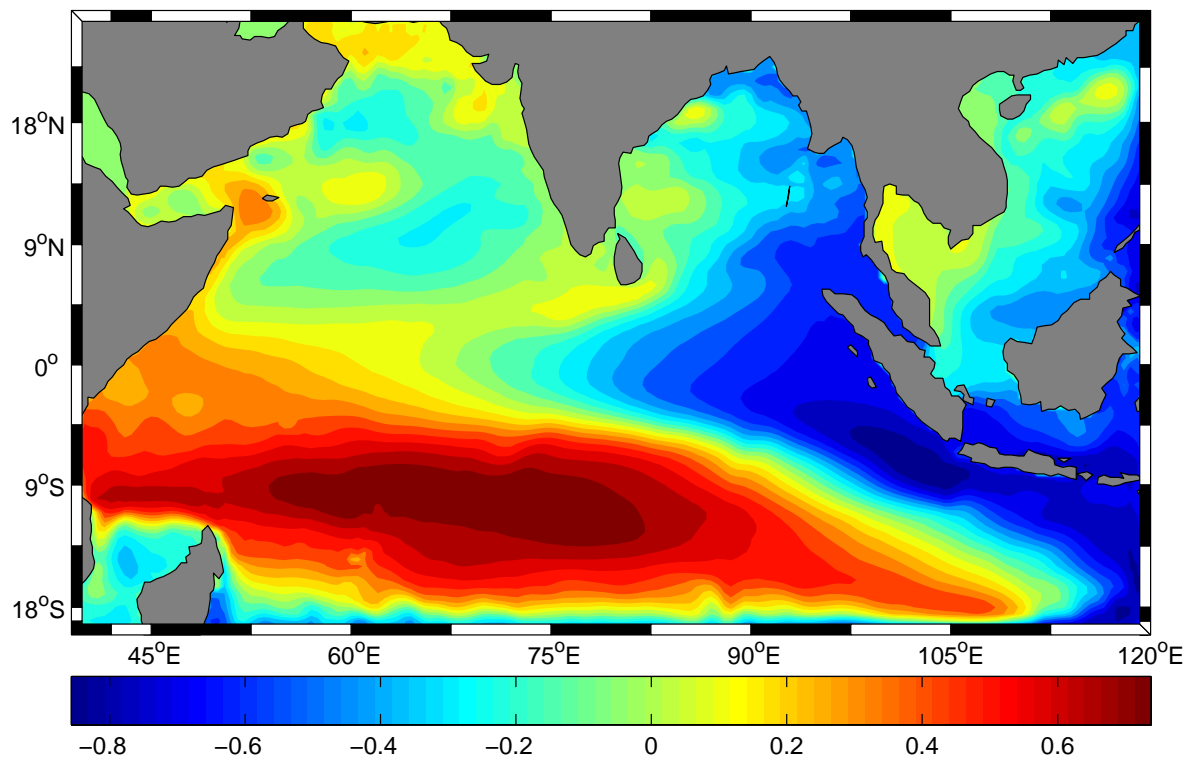

Fig. 10. Spatial variability for the 4th SSH mode from cEOF analysis with SST. Contours greater than \pm 0.141 (in absolute value) are statistically significant at the $95 \%$ level.
Indian Ocean variability during the IOD

\section{J. Brown et al.}

\section{Title Page}

Abstract

Introduction

Conclusions

References

Tables

Figures

14

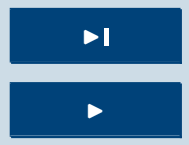

Back

Close

Full Screen / Esc

Printer-friendly Version

Interactive Discussion 


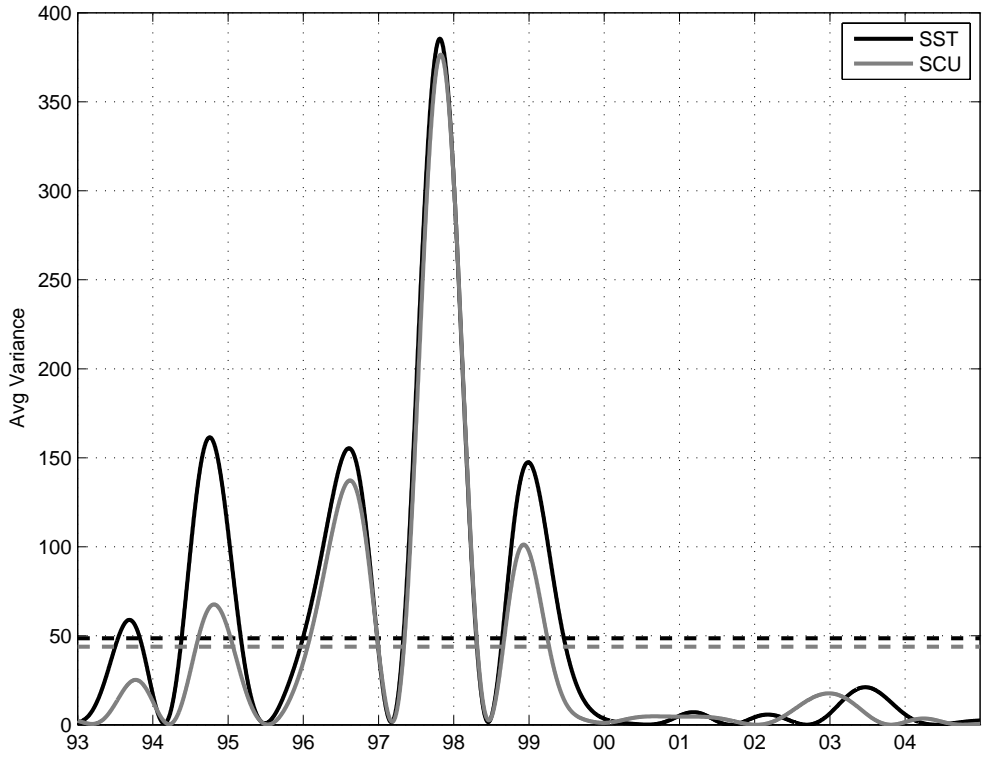

Indian Ocean variability during the IOD

J. Brown et al.

Title Page

\section{Abstract}

Conclusions

Tables

14

4 References

\section{Figures}

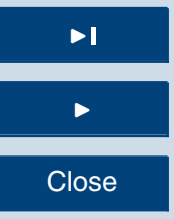

Full Screen / Esc

Printer-friendly Version

Interactive Discussion 
OSD

5, 213-253, 2008

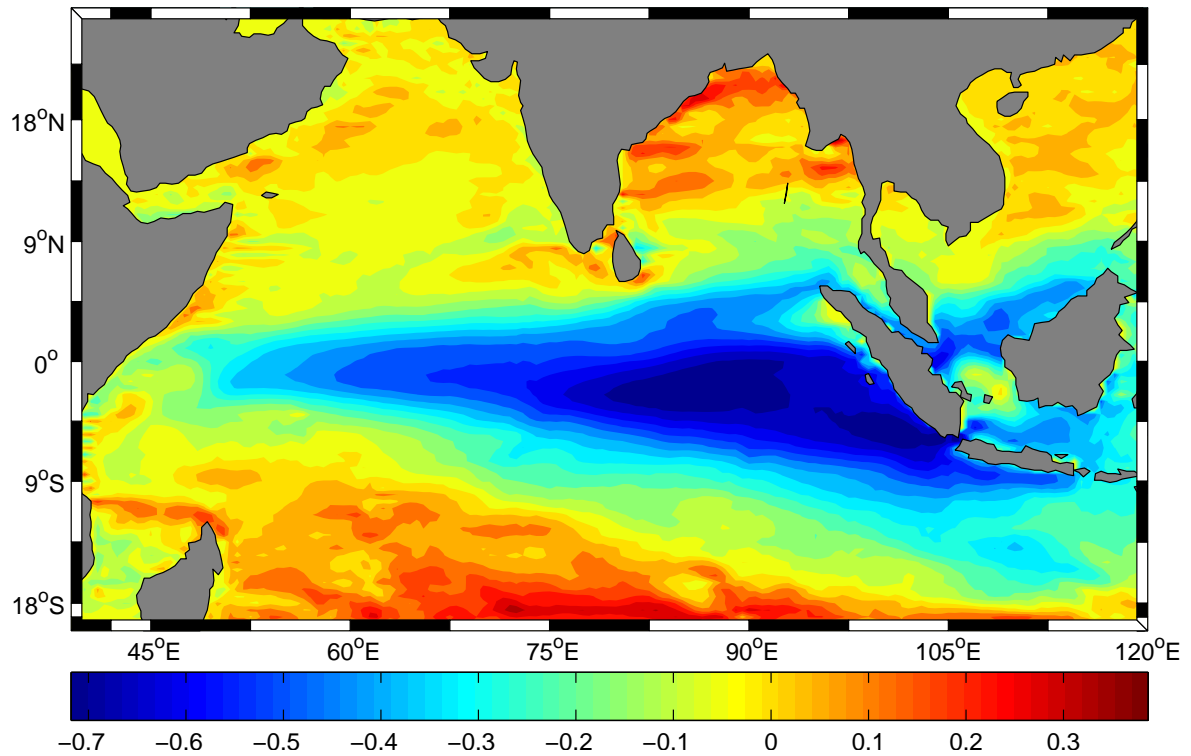

Fig. 12. Spatial variability for the 4th SCU mode from cEOF analysis with SST. Contours greater than \pm 0.129 (in absolute value) being statistically significant at the $95 \%$ level.

\section{Indian Ocean variability during the IOD \\ J. Brown et al.}

\section{Title Page}

Abstract

Introduction

Conclusions

References

Tables

Figures

14

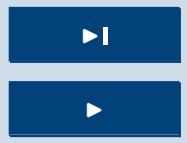

Back

Close

Full Screen / Esc

Printer-friendly Version

Interactive Discussion 


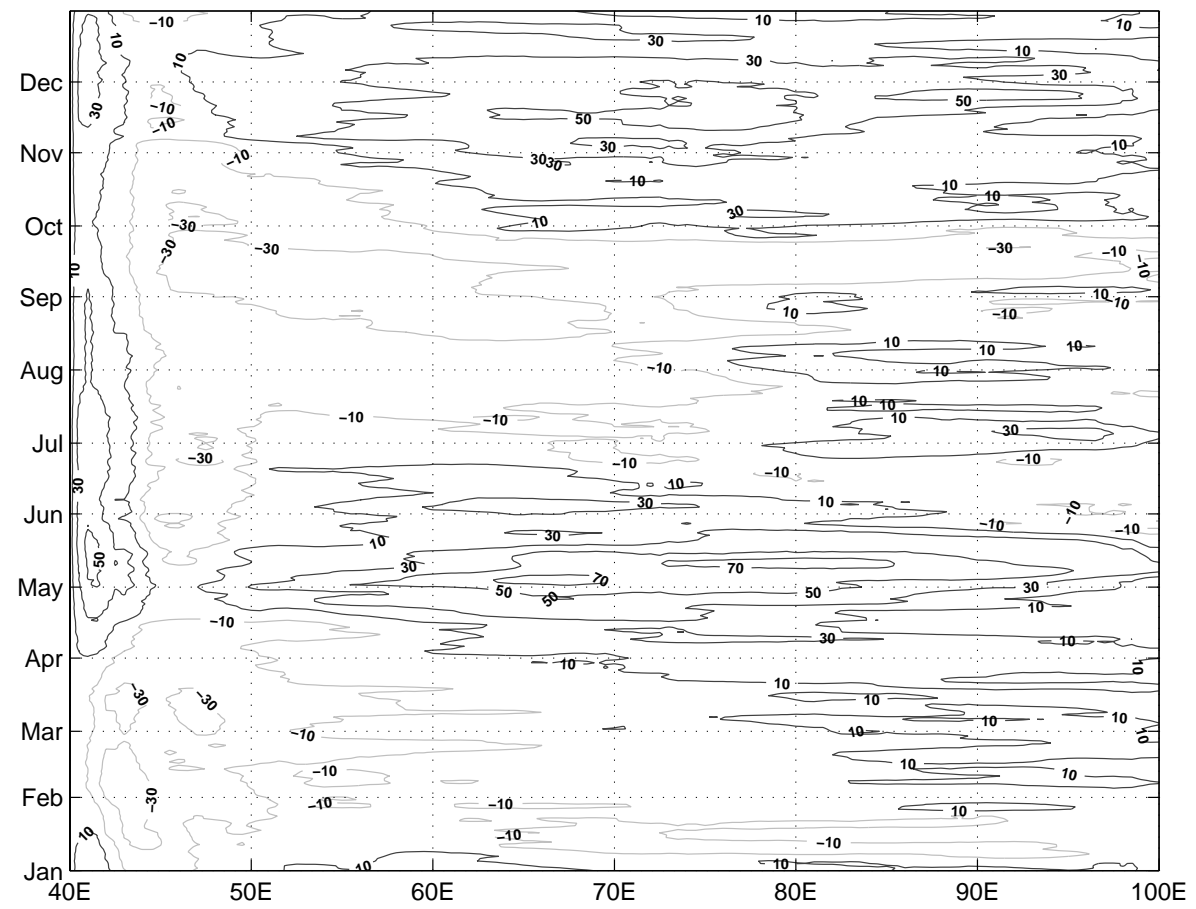

Fig. 13. 2000-2004 daily averaged zonal surface current (SCU) evolution in $\mathrm{cm} \mathrm{s}^{-1}$. Values are averaged between $3^{\circ} \mathrm{S}$ and $0^{\circ}$. The range of positive SCU (black contours) is 10 to $70 \mathrm{~cm} \mathrm{~s}^{-1}$. Negative SCU (gray contours) values extend from -30 to $-10 \mathrm{~cm} \mathrm{~s}^{-1}$. Both positive and negative contours are presented in increments of $20 \mathrm{~cm} \mathrm{~s}^{-1}$.
OSD

5, 213-253, 2008

Indian Ocean variability during the IOD

J. Brown et al.

Title Page

Abstract

Introduction

Conclusions

References

Tables

Figures

14

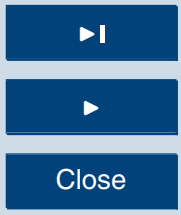

Back

Close

Full Screen / Esc

Printer-friendly Version

Interactive Discussion 


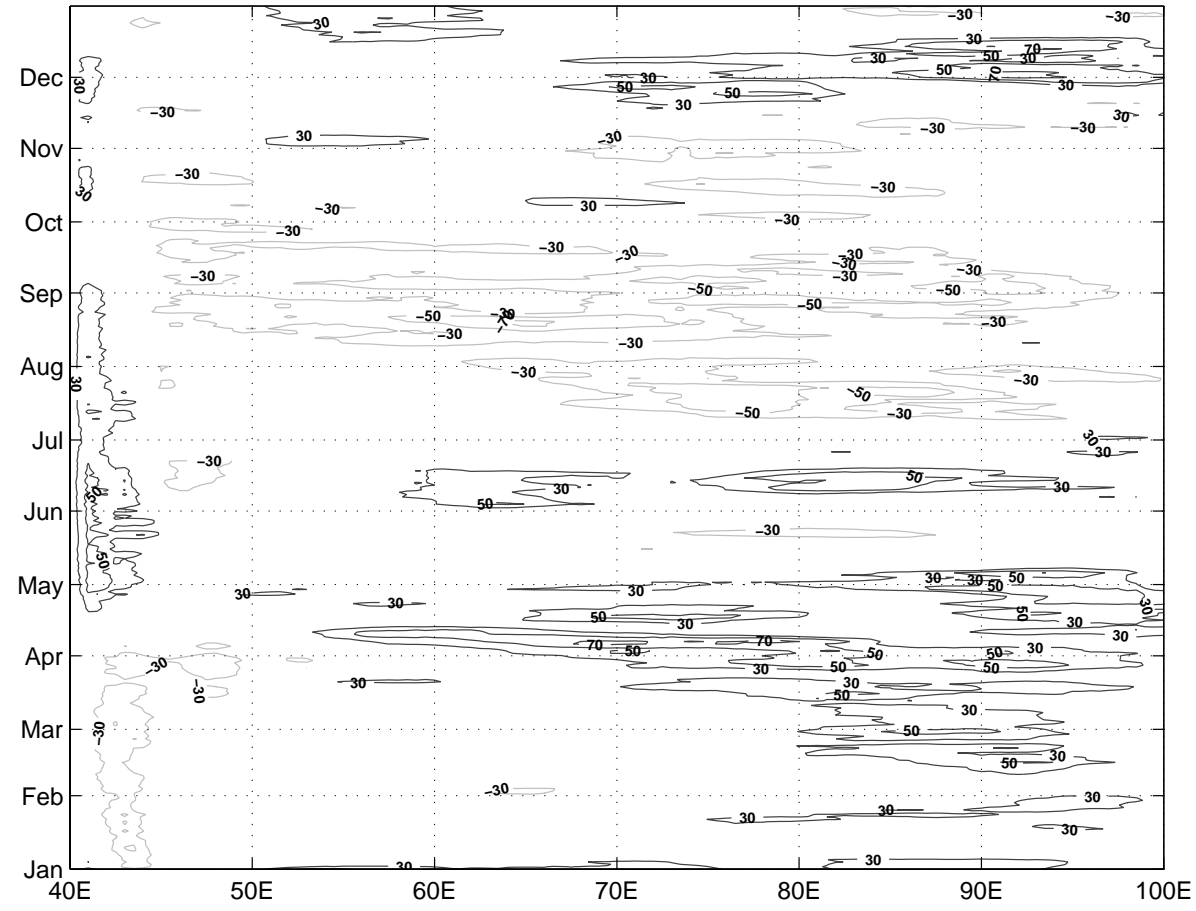

Fig. 14. SCU evolution in $\mathrm{cm} \mathrm{s}^{-1}$ during the positive IOD of 1994. Values are averaged between $3^{\circ} \mathrm{S}$ and $0^{\circ}$. The range of positive SCU (black contours) is 30 to $70 \mathrm{~cm} \mathrm{~s}^{-1}$. Negative SCU (gray contours) values extend from -70 to $-30 \mathrm{~cm} \mathrm{~s}^{-1}$. Both positive and negative contours are presented in increments of $20 \mathrm{~cm} \mathrm{~s}^{-1}$.
OSD

$5,213-253,2008$

Indian Ocean variability during the IOD

J. Brown et al.

\section{Title Page}

Abstract

Introduction

Conclusions

References

Tables

Figures

14

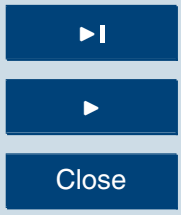

Back

Close

\section{Full Screen / Esc}

Printer-friendly Version

Interactive Discussion 


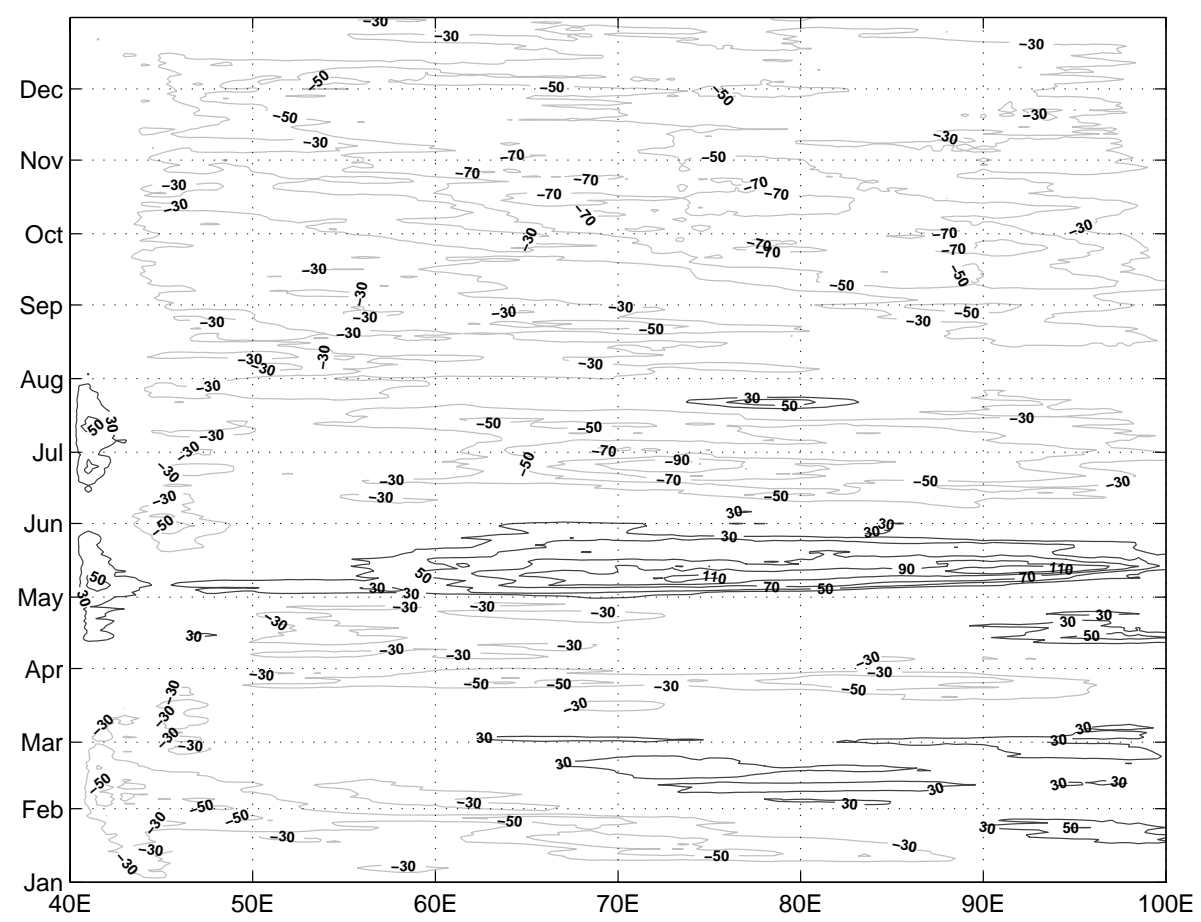

Fig. 15. SCU evolution in $\mathrm{cm} \mathrm{s}^{-1}$ during the positive IOD of 1997. Values are averaged between $3^{\circ} \mathrm{S}$ and $0^{\circ}$. The range of positive SCU (black contours) is 30 to $110 \mathrm{~cm} \mathrm{~s}^{-1}$. Negative SCU (gray contours) values extend from -70 to $-30 \mathrm{~cm} \mathrm{~s}^{-1}$. Both positive and negative contours are presented in increments of $20 \mathrm{~cm} \mathrm{~s}^{-1}$.
OSD

$5,213-253,2008$

Indian Ocean variability during the IOD

J. Brown et al.

\section{Title Page}

Abstract

Introduction

Conclusions

References

Tables

Figures

14

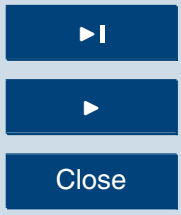

Back

Close

Full Screen / Esc

Printer-friendly Version

Interactive Discussion 


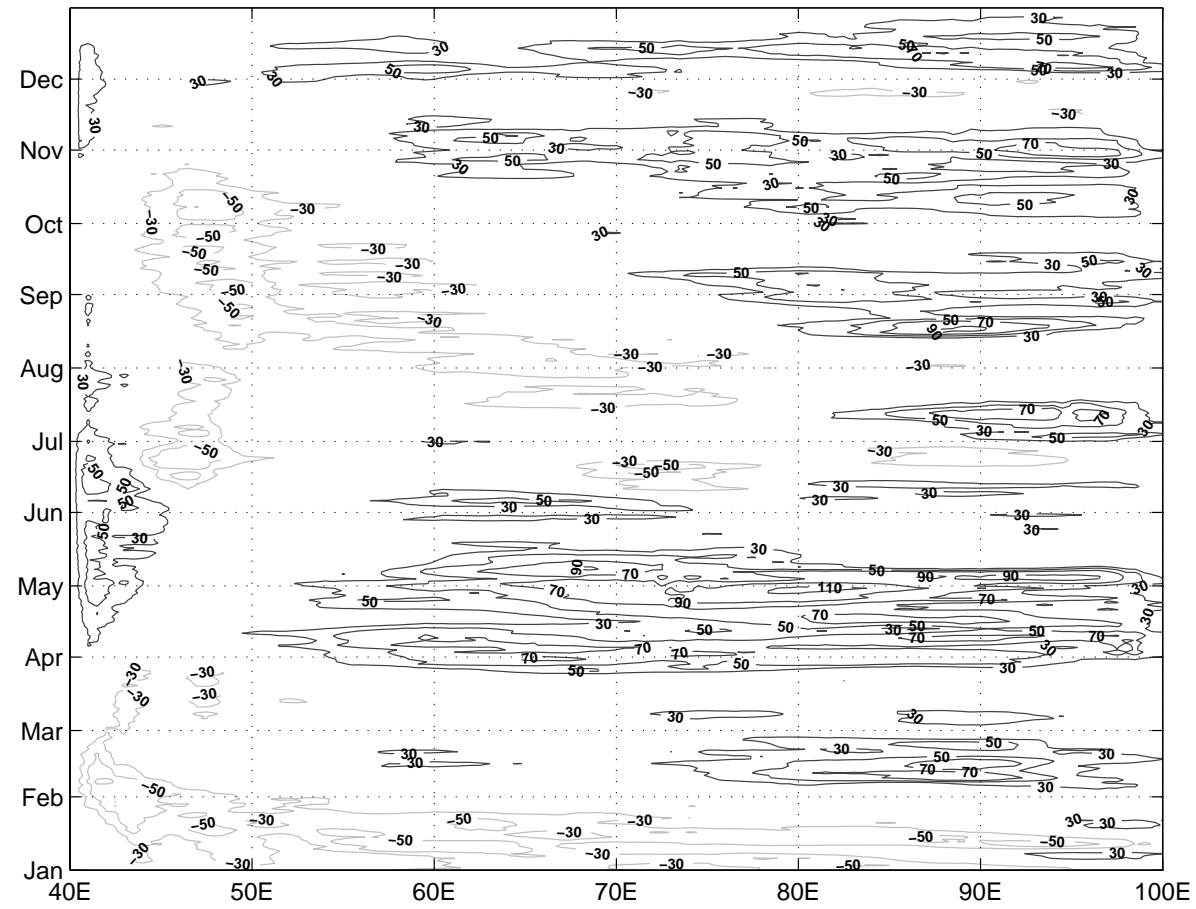

Fig. 16. SCU evolution in $\mathrm{cm} \mathrm{s}^{-1}$ during the negative IOD of 1996. Values are averaged between $3^{\circ} \mathrm{S}$ and $0^{\circ}$. The range of positive SCU (black contours) is 30 to $110 \mathrm{~cm} \mathrm{~s}^{-1}$. Negative $\mathrm{SCU}$ (gray contours) values extend from -50 to $-30 \mathrm{~cm} \mathrm{~s}^{-1}$. Both positive and negative contours are presented in increments of $20 \mathrm{~cm} \mathrm{~s}^{-1}$.
OSD

$5,213-253,2008$

Indian Ocean variability during the IOD

J. Brown et al.

Title Page

Abstract

Introduction

Conclusions

References

Tables

Figures

14

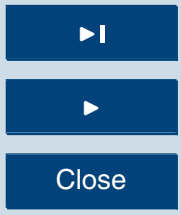

Back

Close

Full Screen / Esc

Printer-friendly Version

Interactive Discussion 


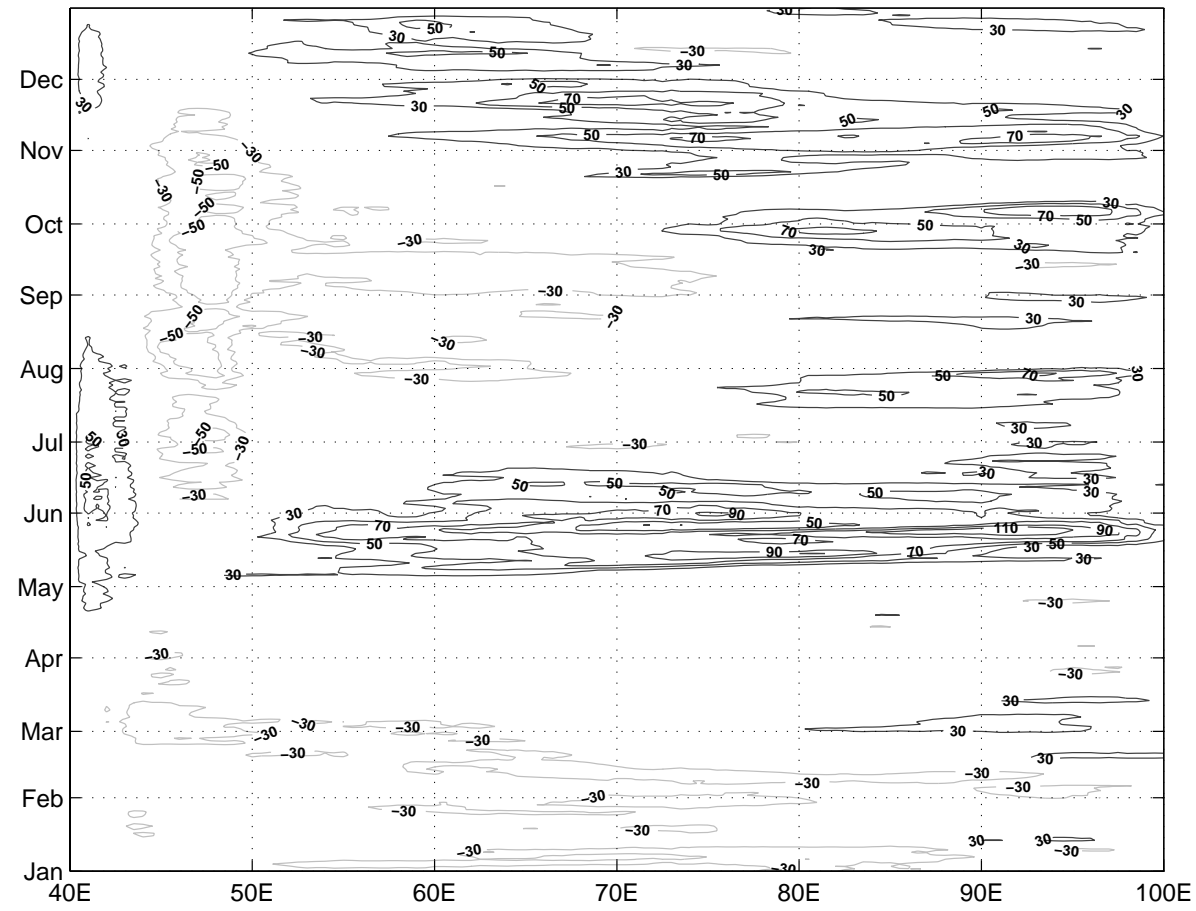

Fig. 17. SCU evolution in $\mathrm{cm} \mathrm{s}^{-1}$ during the negative IOD of 1998. Values are averaged between $3^{\circ} \mathrm{S}$ and $0^{\circ}$. The range of positive SCU (black contours) is 30 to $\mathrm{cm} \mathrm{s}^{-1}$. Both positive and negative contours are presented in increments of $20 \mathrm{~cm} \mathrm{~s}^{-1}$.
OSD

$5,213-253,2008$

Indian Ocean variability during the IOD

J. Brown et al.

\section{Title Page}

Abstract

Introduction

Conclusions

References

Tables

Figures

14

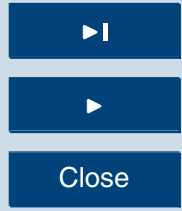

Back

Close

\section{Full Screen / Esc}

Printer-friendly Version

Interactive Discussion 


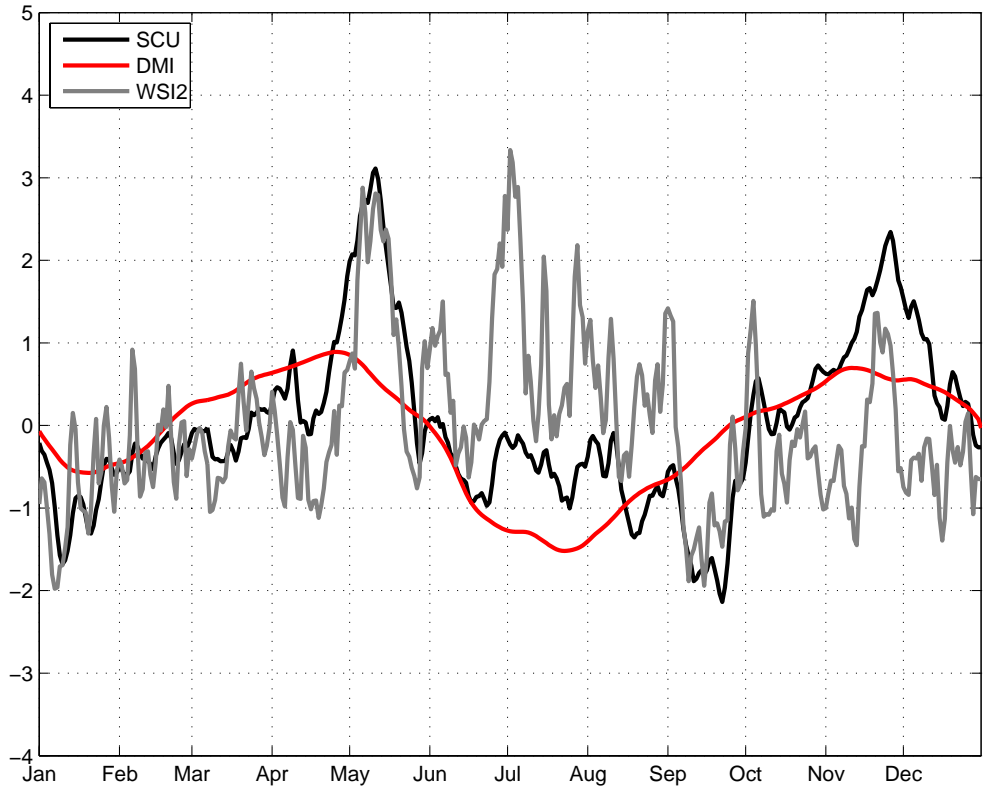

Fig. 18. Comparison of the SCU (averaged over $3^{\circ} \mathrm{S}$ to $0^{\circ}$ and $70^{\circ} \mathrm{E}$ to $95^{\circ} \mathrm{E}$ ), the dipole mode index (DMI), and the zonal wind stress index (WSI2, averaged over $5^{\circ} \mathrm{S}$ to $5^{\circ} \mathrm{N}$ and $80^{\circ} \mathrm{E}$ to $95^{\circ} \mathrm{E}$ ) during the non-IOD years of 2000-2004. The SCU (black line) and the WSI2 (gray line) are daily averaged for 2000-2004, and then the area average is estimated. The DMI is daily averaged from the values in Fig. 3 for the 2000-2004 period. Each time series has the mean removed and is normalized by its respective standard deviation for comparison.
5, 213-253, 2008

\section{Indian Ocean variability during the IOD}

J. Brown et al.

\section{Title Page}
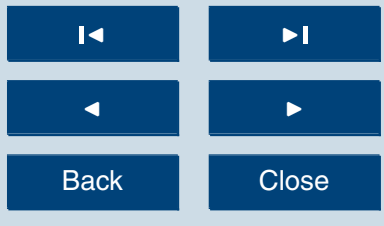

Full Screen / Esc

Printer-friendly Version

Interactive Discussion 


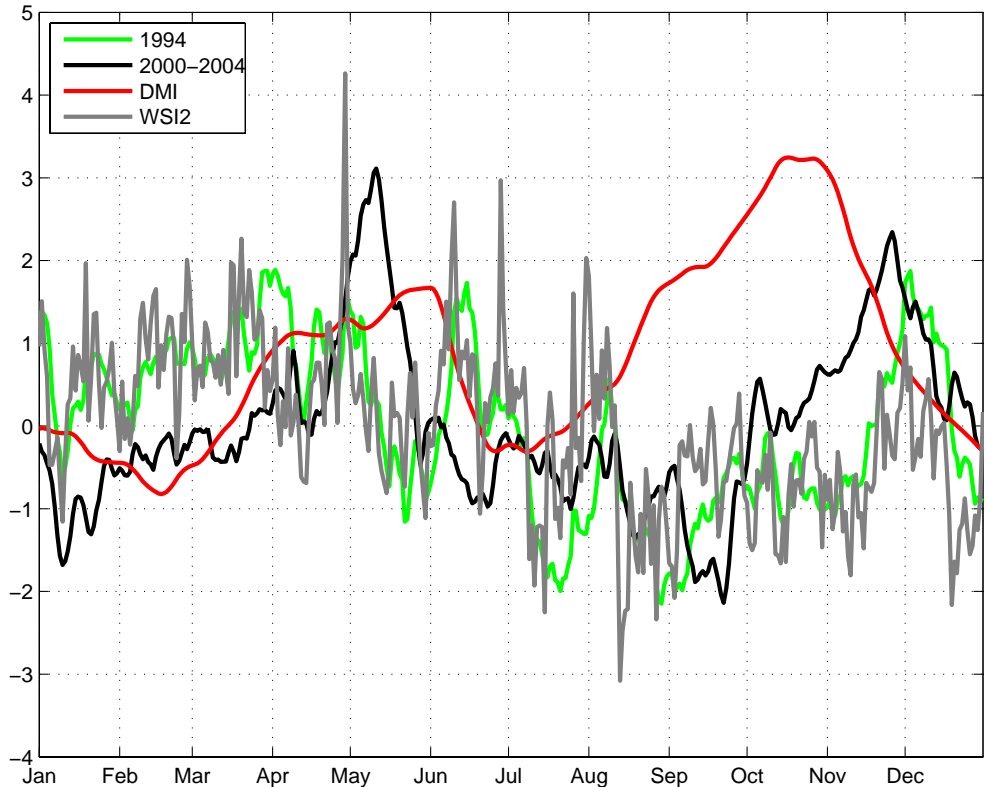

Fig. 19. Comparison of the SCU (averaged over $3^{\circ} \mathrm{S}$ to $0^{\circ}$ and $70^{\circ} \mathrm{E}$ to $95^{\circ} \mathrm{E}$ ) for 1994 (green line) and 2000-2004 (black line), the dipole mode index (DMI) for 1994, and the zonal wind stress index (WSI2, averaged over $5^{\circ} \mathrm{S}$ to $5^{\circ} \mathrm{N}$ and $80^{\circ} \mathrm{E}$ to $95^{\circ} \mathrm{E}$ ) during 1994 . The SCU (black line) is daily averaged for $2000-2004$, and then the area average is estimated. The DMI is daily averaged from the values in Fig. 3 for the 2000-2004 period. Each time series has the mean removed and is normalized by its respective standard deviation for comparison.
5, 213-253, 2008

\section{Indian Ocean variability during the IOD}

J. Brown et al.

\section{Title Page}
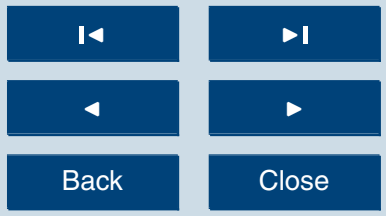

\section{Full Screen / Esc}

Printer-friendly Version

Interactive Discussion 
OSD

5, 213-253, 2008

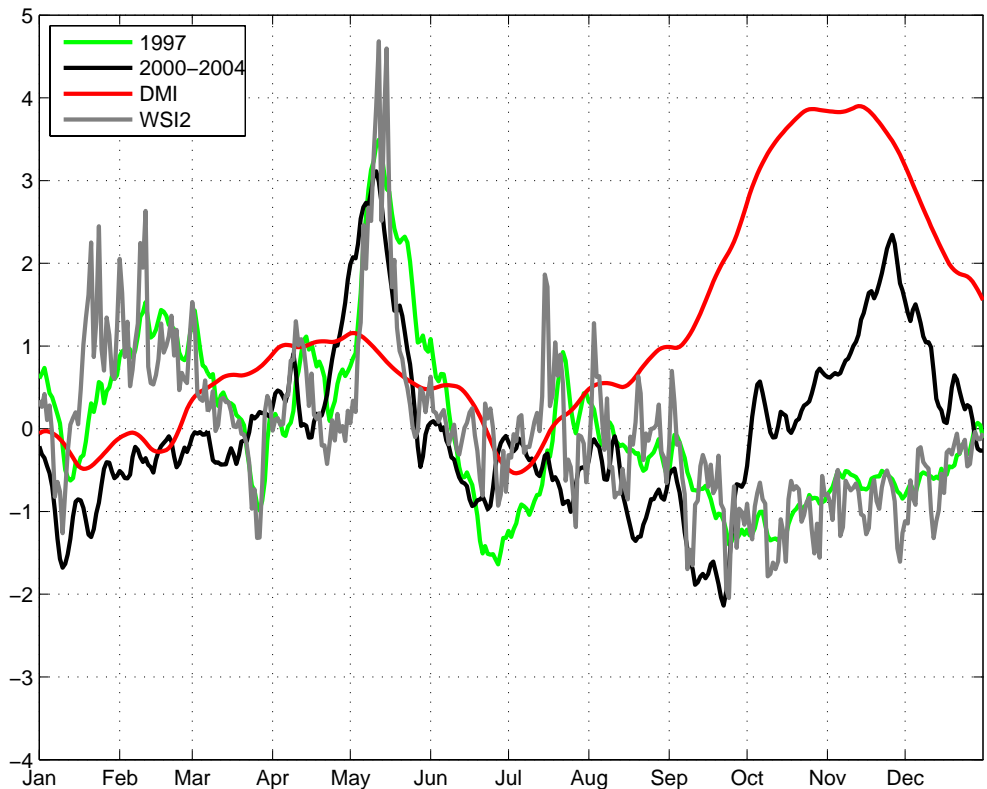

Indian Ocean variability during the IOD

J. Brown et al.

Title Page

Abstract

Introduction

Conclusions

References

Tables

Figures

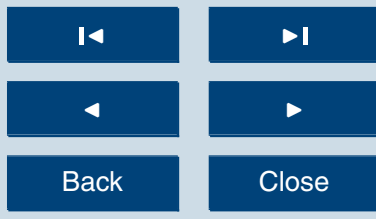

Full Screen / Esc

Fig. 20. Same description as that of Fig. 19 for 1997.

Printer-friendly Version

Interactive Discussion 
OSD

5, 213-253, 2008

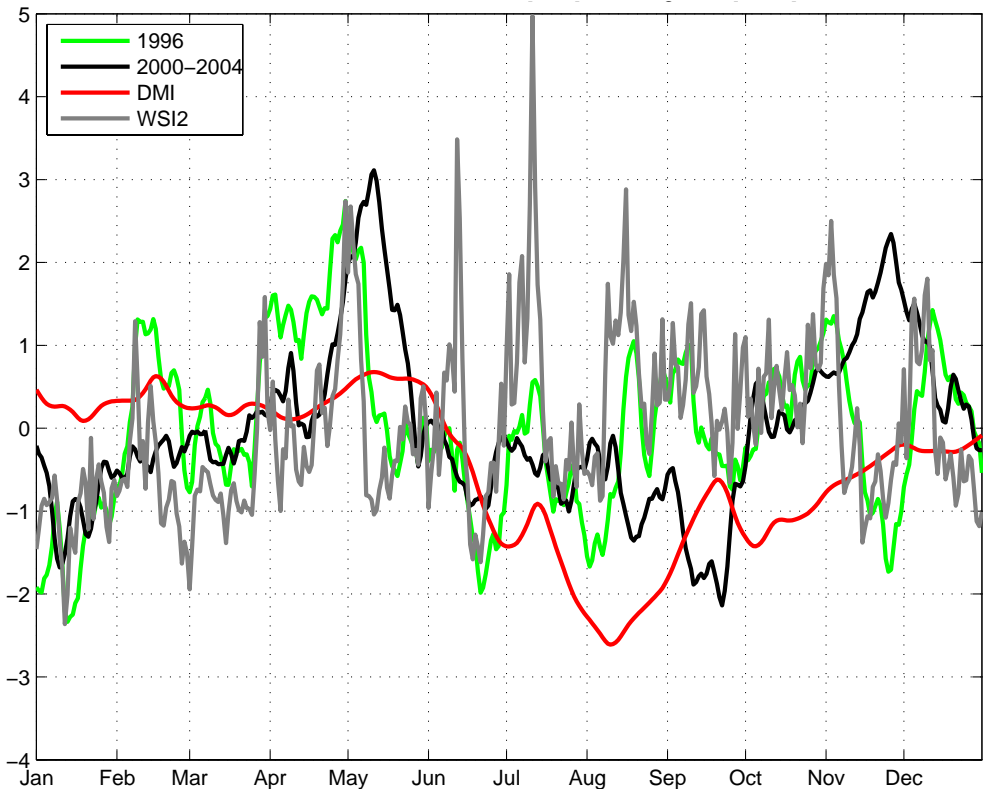

Indian Ocean variability during the IOD

J. Brown et al.

Title Page

Abstract

Conclusions

Tables

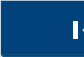

14

Back

Introduction

References

Figures

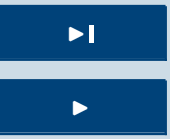

Close

Full Screen / Esc

Printer-friendly Version

Interactive Discussion 
OSD

5, 213-253, 2008

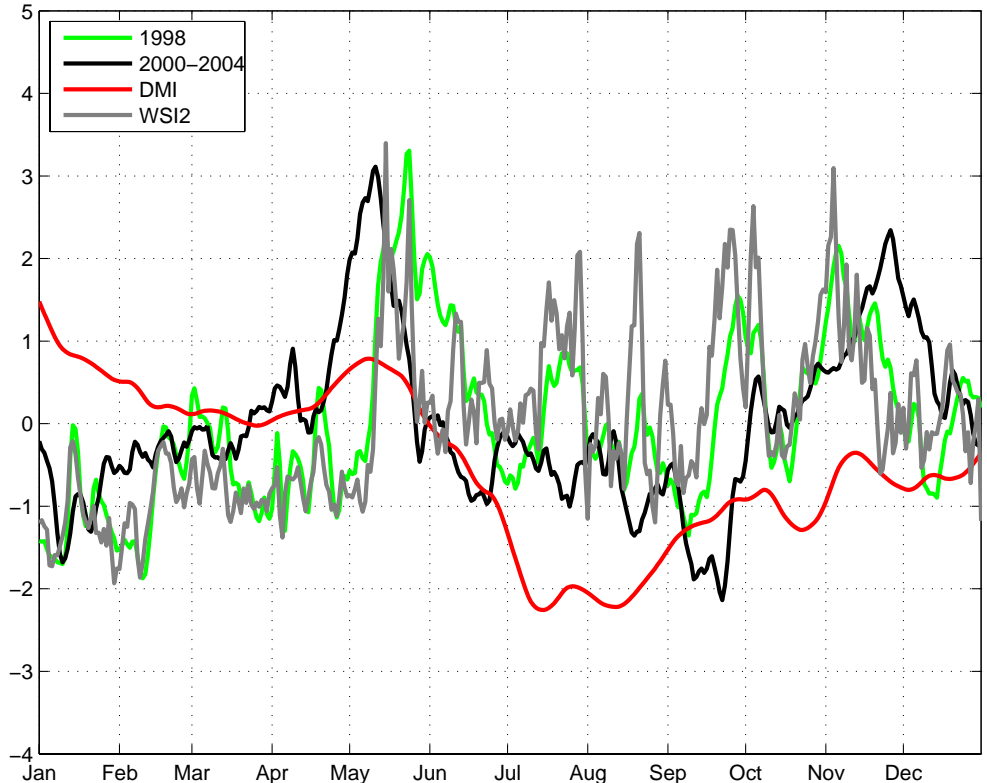

Indian Ocean variability during the IOD

J. Brown et al.

Title Page

Abstract

Conclusions

Tables

14

4

Back

Introduction

References

Figures

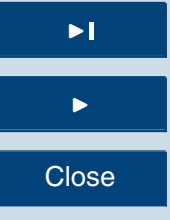

Full Screen / Esc

Printer-friendly Version

Interactive Discussion 